\title{
A Critical Examination of Models Regarding a Han 韓 - Ye 濊 Ethnic Division in Proto-Historic Central Korea, and Further Implications
}

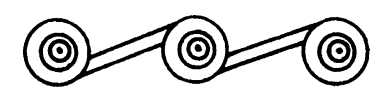

\author{
Hari Blackmore
}

\begin{abstract}
This critical review re-considers the logic behind accounts of ethnic groups represented in the proto-historic records of Korea, specifically in terms of the 'Han' 韓 and 'Ye(maek)' 濊貃 in the Central Region of South Korea, dated about 100 B.C.E.-C.E. 300 . In the prevailing Chungdo (RR: Jungdo) type Culture model, the 'Han' 韓 people were part of the Mahan confederation of polities in the west, while the 'Ye(maek)' 減貃 people lived in the north and east. Details vary in the criteria used to define these two 'peoples', for example in classifying Stone Mound Tombs as 'Ye', hypocaust systems as 'Han', or pots with externally angled rims as 'Han'. The present review reveals that Stone Mound Tombs did not appear until perhaps C.E. 250-300, near the end of the period thought to be associated with the 'Ye'. Additionally, some form of boundary appears to have existed between the Han River Basin and the southwestern part of Korea, although such would be unclear in conventional models of Han and Ye territories. Potential implications can now be discussed more productively regarding the formation of the Paekche state and interactions between the Korean peninsula and maritime Siberia, previously overlooked due to a focus on the Yellow Sea and Lelang commandery. This review recommends that future work would be more fruitful and reflective of past lived reality if based upon material use contexts and the identification of common social institutions. KEYwORDS: Korean Iron Age, Mahan 馬韓, Ye 濊-Malgal 靺鞨, proto-history, ethnicity, archaeological practice.
\end{abstract}

\section{INTRODUCTION}

The “Late Iron Age," "Proto-Three Kingdoms," or "Samhan” period (ca. 100 B.C.E.-C.E. 300) was an important and complex time for the southern part of the Korean Peninsula, as it set the stage for the emergence in the late third to early fourth centuries of the states of Paekche 百濟 (Revised Romanization [hereafter RR]: Baekje) in the Han River basin and Silla 新羅 in the southwestern part of the peninsula. The term 'Late Iron Age' is adopted here as being the most inclusive of societies that do not appear in historical texts or did not go on to form states (for review of period 
nomenclature, see Barnes 2001:80-90; Ju 2009:114-117). This period is one where a great many cultural exchanges develop across the peninsula, with the influence of the Imperial Han 漢 commandery of Lelang 樂浪 looming large in the north. Lelang provided a contact point between the Chinese state and various peninsular groups, of which the “Three Han” known as the Mahan 馬韓, Chinhan 辰韓 (RR: Jinhan), and Pyŏnhan 弁韓 (RR: Byeonhan) have perhaps been the most extensively studied archaeologically (Fig. 1). Cultural exchanges also solidify between southern Korea and Yayoi Japan (Barnes 2015:322-323) and between eastern Korea and maritime Siberia (Kor. 연 해주; Rus. Primorsky Krai), that is, the far eastern Russian coast. The Korean Late Iron Age is therefore critical for examining both state formation processes and issues of cultural contact between empires and their border regions.

During the Late Iron Age, an entity termed the 'Chungdo (RR: Jungdo) type Culture' 中島類型文化 is proposed to have emerged in the Central Region of South Korea, occupying the Imjin River region and the area east of the lower Han River in eastern Kyŏnggi (RR: Gyeonggi) Province (Fig. 2) (Pak S. 1996). Pak Sunbal (1996, 2001a:75-85) defines this "culture" with reference to specific aspects of the archaeological assemblage via the co-occurrence of pottery types (red/brown earthenware called Hard Plain Pottery 硬質無文土器, grey or brown/red stoneware called Paddled Patterned Pottery 打捺文土器, and “stoneware” Grey Plain Pottery 灰黑色 無文樣土器) (Fig. 3), yŏ 呂 (RR: yeo) and ch'ŏl 凸 (RR: cheol) shaped architecture (Fig. 4), and Stone Mound Tombs (Kor. chŭpsŏksik chŏksŏk myo 莫石式積石墳) (Fig. 5). Particular emphasis is placed on the latter element, essentially because all the other elements are distributed across all areas of Kangwŏn (RR: Gangwon), Kyŏnggi, and the Seoul area. A number of other scholars do not use the designation "Chungdo type Culture," yet acknowledge the core meaningfulness of one or more of the above archaeological elements for constructing their own cultural models and often use the original model as a starting point for critique or modification (e.g., Pak C. 2012; No 2004; Yu 2006, 2014).

Various other authors have noted the extent of regional variation within Central Korea (e.g. Kwŏn Oyŏng 2009, 2010; Pak C. 2012; Yi S. 2009; Yu 2006). Such differences are often linked to distinctions between the so-called "ethnic" groups of 'Han 韓 and 'Ye 濊,' names which appear in ancient Chinese and medieval Korean historical texts (Pak C. 2011, 2012; Pak S. 1996, 2001a; Yu 2006). Thus, the Chungdo type Culture (and its descendants) is attached to the Ye in contrast to the Han group, which, having been part of the Mahan Confederacy, is posited to occupy the lower Han River basin around modern day Seoul and southern Kyŏnggi. Regardless of the particular units used to propose various cultural models and boundaries, two ideas remain entrenched in literature concerning the Central Region. First, a broad 'Ye (maek) 濊腼' culture exists, and second, two particular “archaeological cultures” are present there (Kwŏn Oyŏng 2010; Pak C. 2012).

A focus on identifying archaeological cultures and mapping their movements and interactions remains dominant in much of the Korean archaeological literature (Bale 2014:110-112), just as such a "Culture-Historical" approach is common for many parts of the world (Trigger 2006:261-278). Indeed, scholars have argued that this is the most appropriate theoretical and methodological approach for any Korean archaeology focused upon the origins of modern Koreans (Ch'oe S. 2005; Kim W. 1986), creating a timetable of ethnic Koreans' history (Kim W. 1986), or supporting established histories (Ch'oe M. 2013:114; Ch'oe and Kim 2005:216, 253-254). In other words, a 


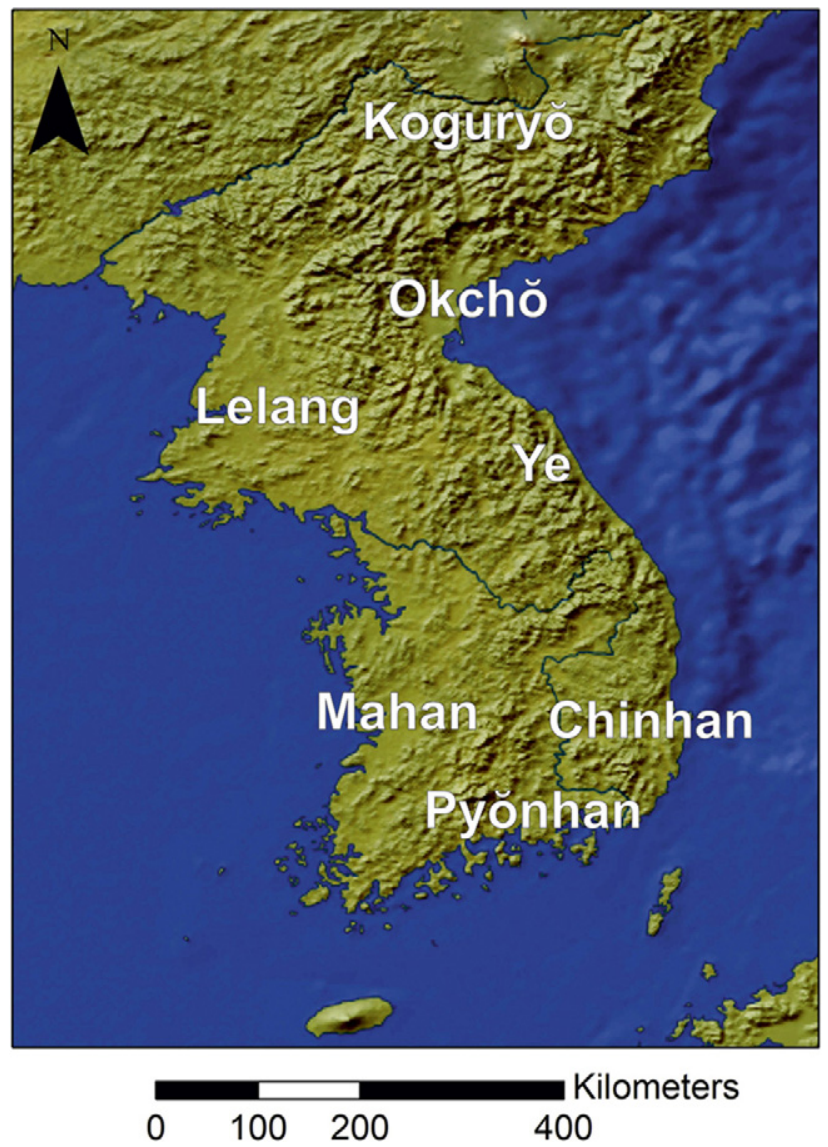

Fig. 1. Commonly understood locations of polities or political formations during the Late Iron Age on the Korean Peninsula. ${ }^{3}$
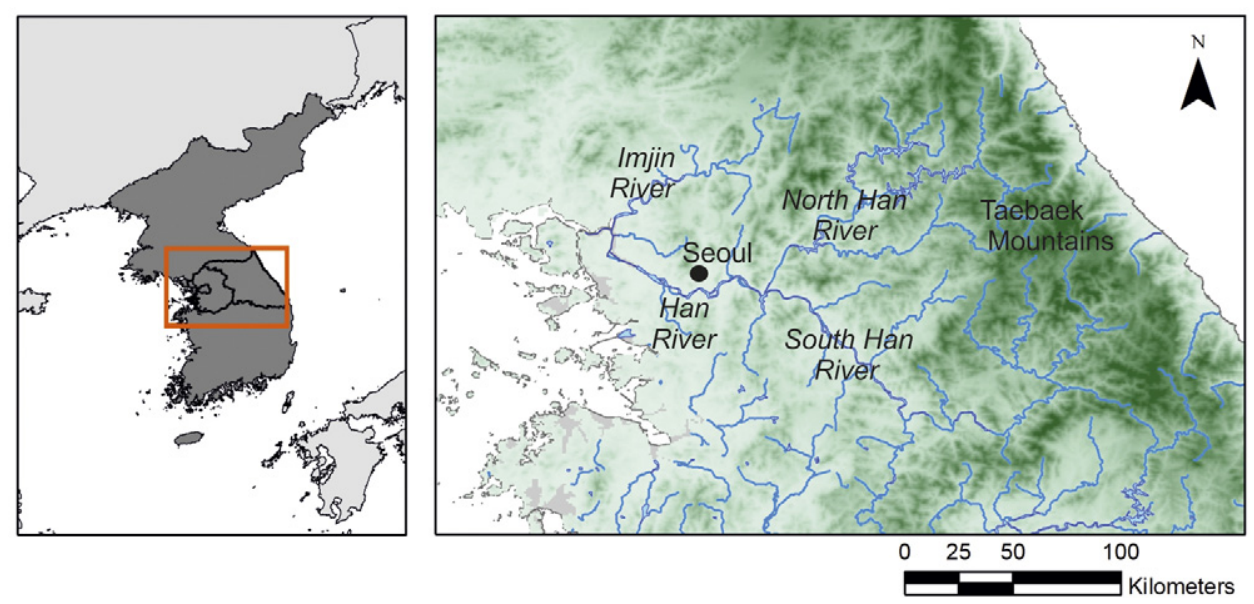

Fig. 2. Geographical overview of Central Region of Korea. Broad-scale map (left) shows boundaries between Seoul and Kyŏnggi Province in the east and Kangwŏn Province to the west. 


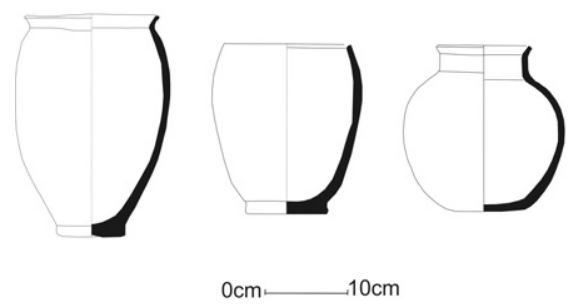

(1)

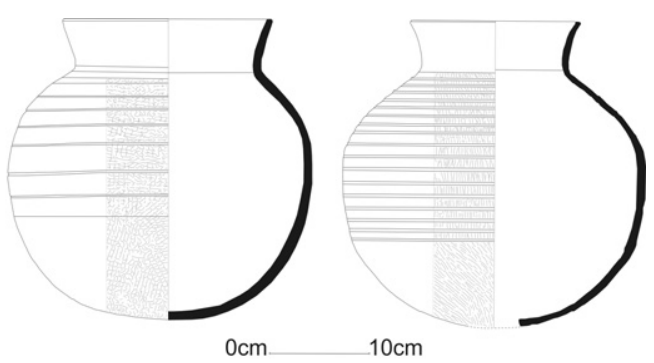

(2)

Fig. 3. Pottery forms from Central Region of Korea, Late Iron Age (100 B.C.E.-C.E. 300) (all redrawn from Kyŏnggi Munhwa Chedan 2009). (1) Common Plain Hard Pottery: (left) pot with externally angled rim 외반구연호 (oeban kuyŏnho) (p. 221, fig. 119-2); (centre) pot with internally angled rim 내만구연호 (naeman kuyŏnho) (p. 354, fig. 179-2); (right) jar with neck 유경호 (yugyŏngho) (p. 240, fig. 129-4); (2) Paddled Patterned short-necked jars: (left) cross hatch pattern (p. 502, fig. 249-2); (right) line pattern (p. 513, fig. 255).
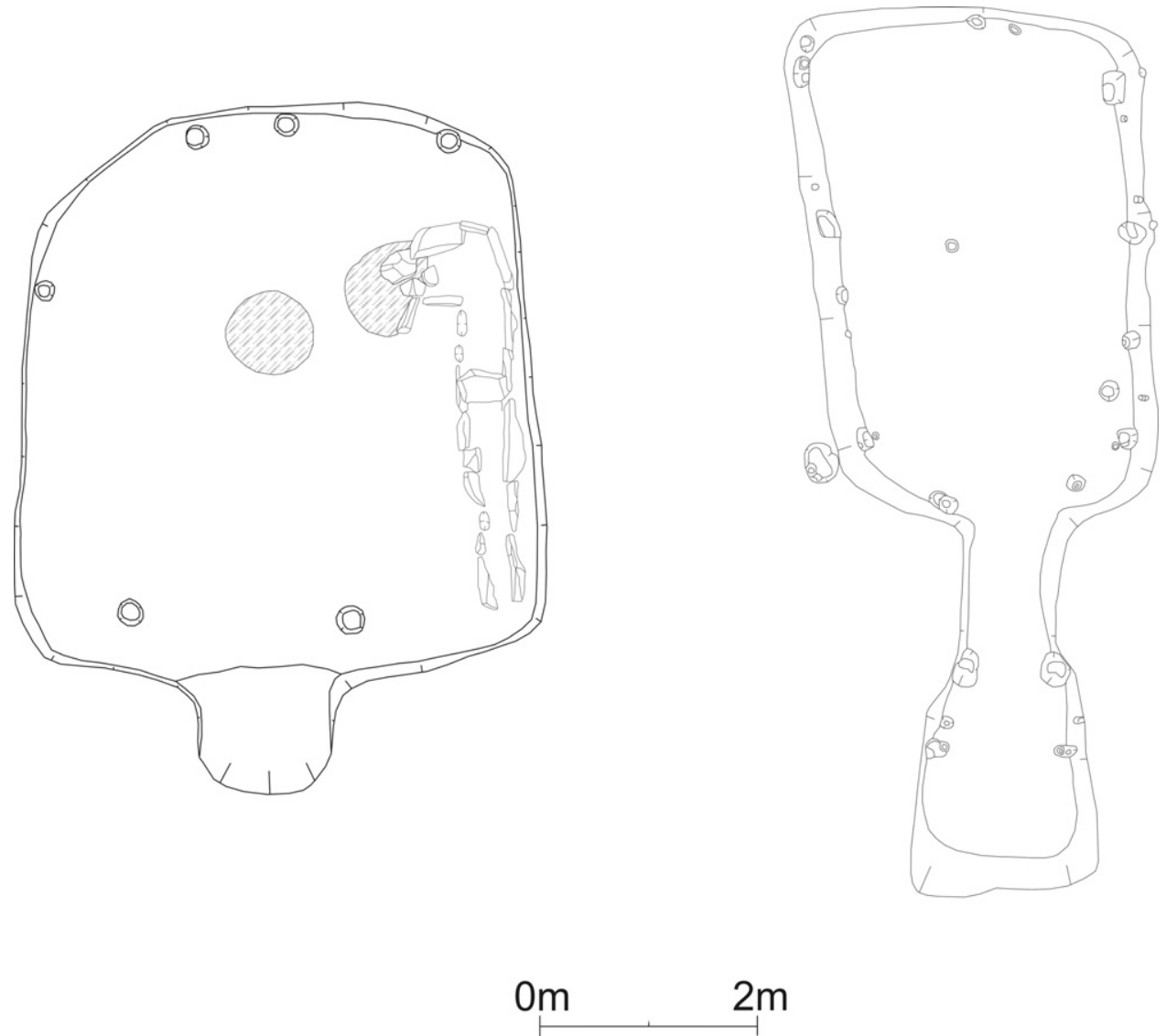

Fig. 4. House features from Central Region of Korea, Late Iron Age (100 B.C.E.-C.E. 300): (left) Ch'ŏl (凸)-shape architecture with hypocaust system on right wall (redrawn from Chungang Munhwajae Yŏn'guwŏn 2014:45, fig. 21); (right) Yŏ (呂)-shape architecture (redrawn from Kyŏre Munhwa Yusan Yŏn'guwŏn 2011:55, fig. 2). 


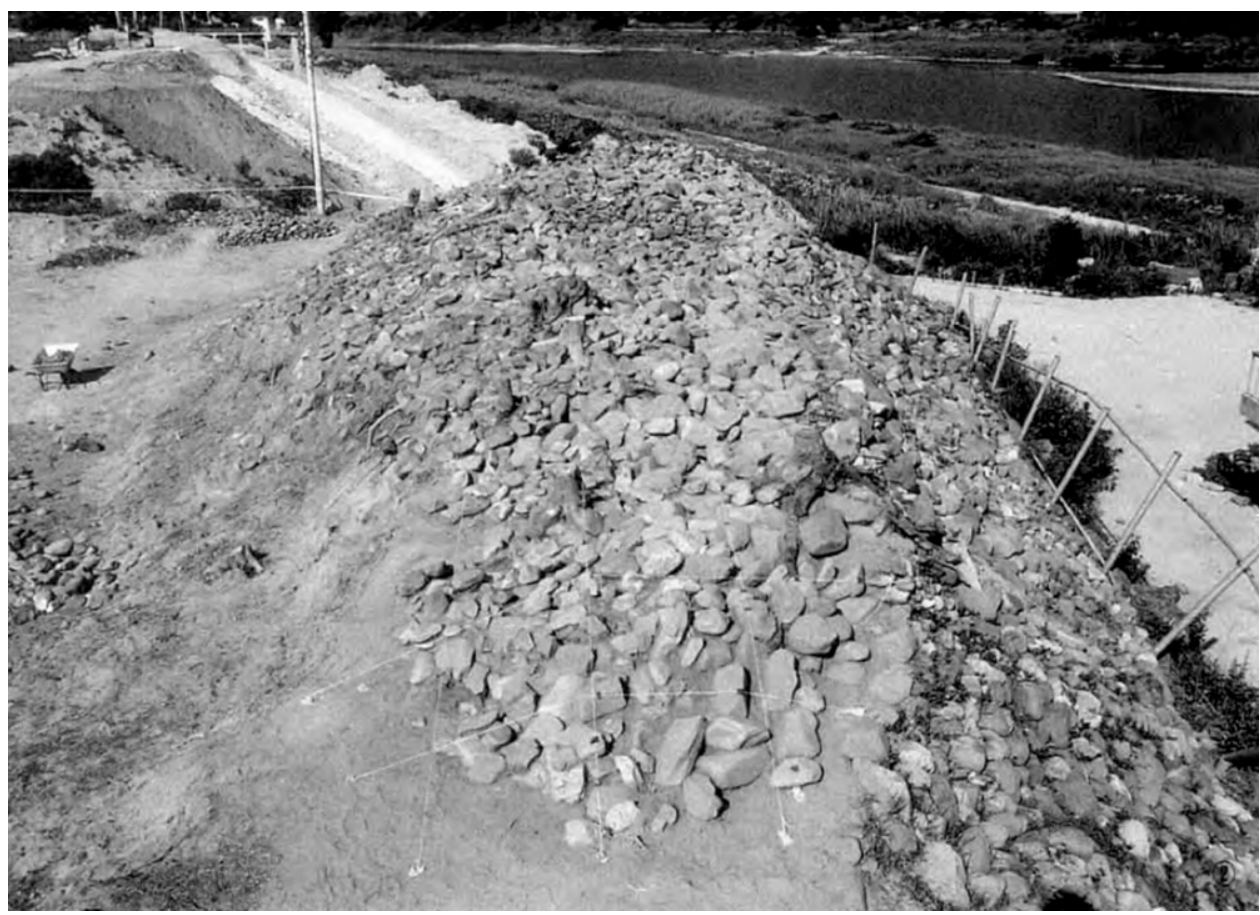

Fig. 5. Stone Mound Tomb from Imjin River basin (reproduced with permission from Kyŏnggi Munhwa Chedan 2004:108, photo 5-2).

nationalist perspective may be seen as having a strong influence on Korean archaeology (Kim Chongil 2008; M. Kim 2008). This very specific view regarding the meaning of, and appropriate roles for, archaeological material prevails.

Such an approach to the material clearly has a Childean nature, with archaeologists searching for sets of material artifacts that regularly co-occur in order to identify and order "peoples" in time and space (Childe 1929:v-vi) and considering elements of material culture to be indices of traditions, institutions, and ways of life (Childe 1933:198-199). The notion that an "archaeological culture" can reflect a past identity group has been critiqued extensively. Among other things, scholars have noted that processes other than group identity affect archaeological patterns (Binford 1962, 1965; Clarke 1978), the groups archaeologists make are products of the present and not necessarily reflective of past peoples (Clarke 1978; Shennan 1989), and that material culture is very rarely a direct correlate of group identity (Hodder 1982; Jones 1997). Much subsequent work in the Anglosphere has gone on to explicitly dismiss the assumptions and methods of the Culture-Historical approach.

Despite this dismissal, others have recently noted that many scholars continue to rely on the archaeological culture concept as a useful heuristic with which to organize their data (even if they call the groups they propose based on the patterns in their datasets by different names) (Jones 1997:29-39; Roberts and Vander Linden 2011:1-2, 8; Trigger 2006:310). Other archaeologists have noted that the abandonment of the CultureHistorical methodology has generated an imbalance favoring the micro-scale, with little developed theory regarding the regional or continental levels (Kristiansen and 
Larsson 2005:4-8). The hard limits of such groupings have been recognized, however. Rather than determining any type of social identity, the non-random distributions of material assemblages are seen as reflective of local and regional interaction networks (Gosselain 2000, 2011; MacEachern 1998; Petrie 2011) or records of which particular material forms are selected for through space and time (O'Brian and Lyman 2009).

Models for the Late Iron Age in Central Korea have not taken into account the theoretical developments mentioned above. They remain rooted in an outlook that assumes particular aspects of material culture reflect social group affiliation. Historical texts also present a complicating factor, with polity or group names that appear in them being applied to archaeological patterns without critical examination or consideration of the limitations of said texts. Pak Sunbal's (1996, 2001a) original proposal, along with the prevailing Childean concept of culture and the expectation that archaeological patterns should support textual evidence, has subsequently framed and constrained the foci of further research on the Central Region during the Late Iron Age.

This article examines the methods, models, and logic that have been and are currently being used to understand this period and geographic area. By calling into question one proposed archaeological culture, it provides a clear example of how Culture-Historical models are built and deployed more generally in Korean archaeology and how they spawn multiple other models, each built upon the same methods and assumptions about the meaning and role of material culture. The focus is firmly on research by Korean scholars, not least because they have done the vast bulk of the work, generating a veritable explosion in data since the late 1990s (Shoda 2008). Since the overwhelming majority of the information is accessible only to readers of Korean, this article also acts as a review of the most recent work and lines of thought regarding important aspects of the Late Iron Age in Central Korea.

Through theoretically and empirically based critiques, I argue that current methods and models for understanding the Late Iron Age in the Central Region have a weak theoretical base and are not representative of the past. In failing to reference the lived traditions, practices, and identities of people in the past, these models are products of present methods, (political) concerns, and trends. The temptation to search for ethnic groups named in the texts, in conjunction with a method that uses singular elements of material culture to define social formations, lacks strong justification and has hampered understanding regarding the dynamics of this period. Indeed, this review reveals that Stone Mound Tombs, which are the primary basis for the Chungdo type Culture model, do not emerge until the very end of the period in question. They are therefore an inappropriate marker of distinction on the model's own terms. This finding impacts our approach to issues of state formation in the Han River basin and wider regional interaction networks in future.

\section{RESEARCH INTO THE CENTRAL REGION'S LATE IRON AGE}

Since the 1990s, an extensive amount of work has been done on the Late Iron Age in the Korean Central Region. Several scholars have set out models regarding apparent archaeological cultures present in the area at this time, along with their potential origins and meanings. A large proportion of the scholarly effort accompanying these models has focused on issues of chronology of external forms and internal features of houses, settlement systems, and pottery chronologies and genealogies, especially for Hard Plain Pottery 硬質無文土器 (kyŏngjil mumun t'ogi [RR: gyeongjil mumun togi]) or 


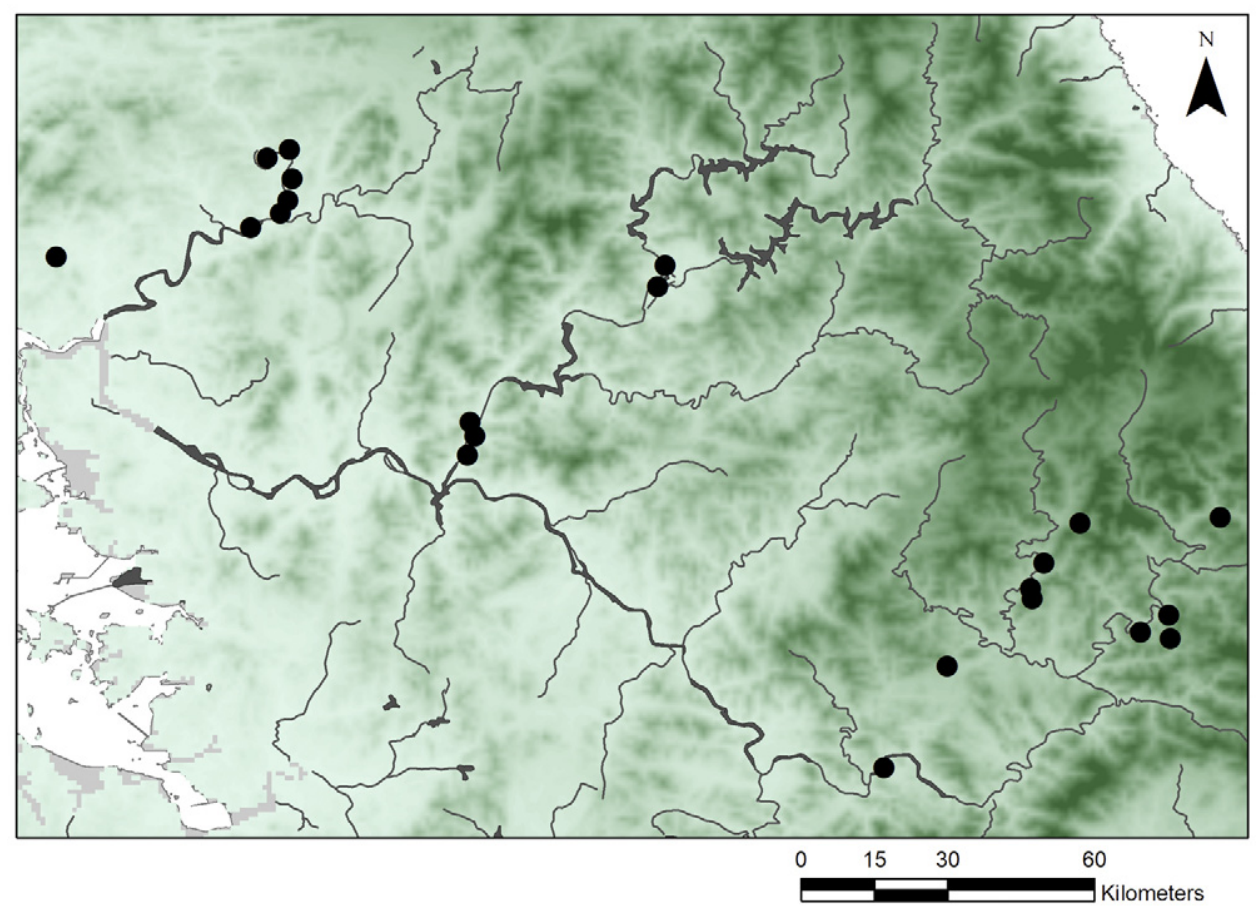

Fig. 6. Distribution of Stone Mound Tombs within Central Region (after Sim Chaeyŏn 2010:153).

Paddled Patterned Pottery 打捺文土器 (t'analmun t'ogi [RR: tanalmun togi]). Such issues are not the focus here, however. Instead, models of the Central Region's society and culture during this period are discussed. My aim is to evaluate whether the "Chungdo type Culture" concept (and others like it) appropriately model the past situation or whether such a description of a uniform archaeological culture is an artifact of the way archaeological material is analyzed and thought about in the present.

Pak Sunbal's (1996:171) Chungdo type Culture is envisioned as an "archaeological culture" consisting of a suite of artifactual, domestic, and funerary features found in the Central Region of the Korean peninsula (Figs. 3-5). Most of the highlighted artifactual and architectural features are spread throughout the Central Region, with the two primary types of pottery, Hard Plain and Paddled Patterned, showing little in the way of significant chronological distinction (although Hard Plain Pottery does appear slightly earlier in Kangwŏn Province) (Kim and Kim 2016). Stone Mound Tombs, however, are focused around the Imjin River basin, upper and mid-streams of the Han River (i.e., eastern Kyŏnggi province), North Han River, and South Han River (Fig. 6). This distinction is seen by Pak Sunbal (1996, 2001a) as indicative of the historical "Ye(kye) 濊系” group, with the presence of Stone Mound Tombs taken as a marker of "Chungdo type Culture." Chungdo type Culture is therefore created in opposition to a "Han" group in the Han River basin, where these tombs are not present (Fig. 7-1). These two groups are identified with reference to the twelfth century text known as the Samguk sagi 三國史記 (History of the Three Kingdoms), particularly the Annals of Paekche volumes, which mention "Ye," "Ye-maek," or “Malgal 靺鞨” raiders coming from the north and northeast, purportedly as early as the 


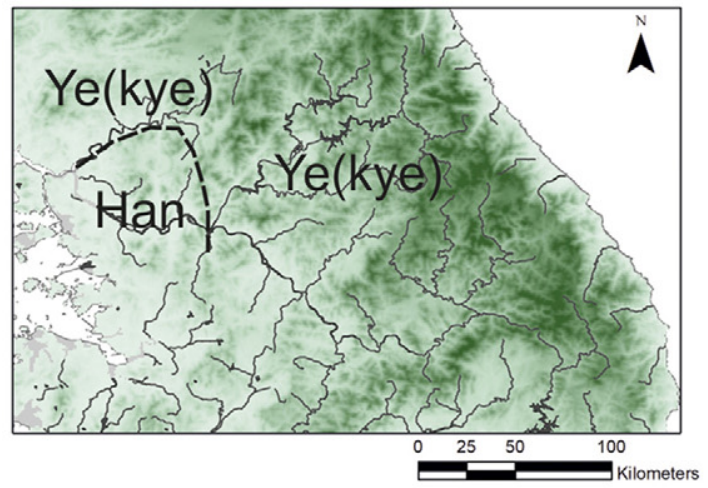

(1)

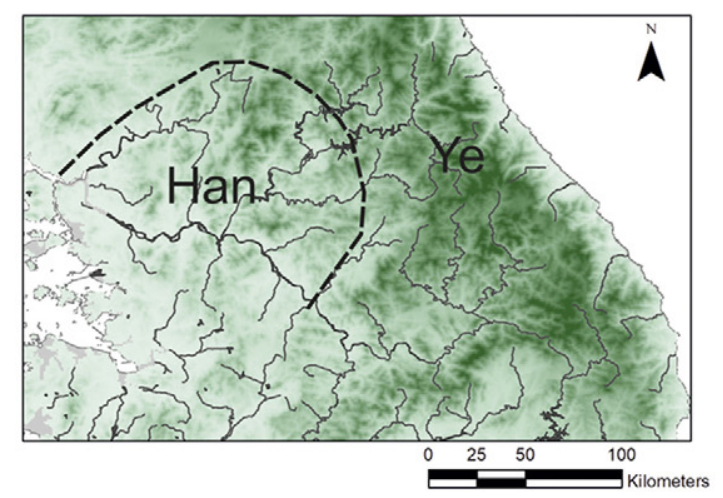

(2)

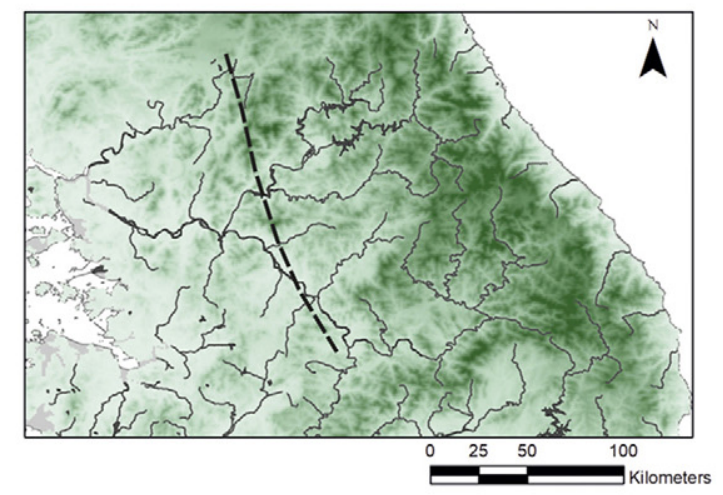

(3)
Fig. 7. Common schemes for understanding the Proto-Historic Korean centre, with group or ethnic divisions based on: (1) distribution of Stone Mound Tombs; (2) presence of hypocaust systems; (3) similarities with material culture and cultivars of Maritime Siberia (east of the boundary line).

first century B.C.E. Pak Sunbal (1996, 2001a) uses these mentions to justify the labeling of those areas as "Ye(kye [RR: gye])." He appears to use the term 'kye 系', here meaning 'bloodline' or 'genealogical descent', to denote people of general Ye stock because the terms 'Ye', 'Ye-maek', and 'Malgal' seem to be used interchangeably in the historical text (Pak S. 2001a:29-30, 138). 


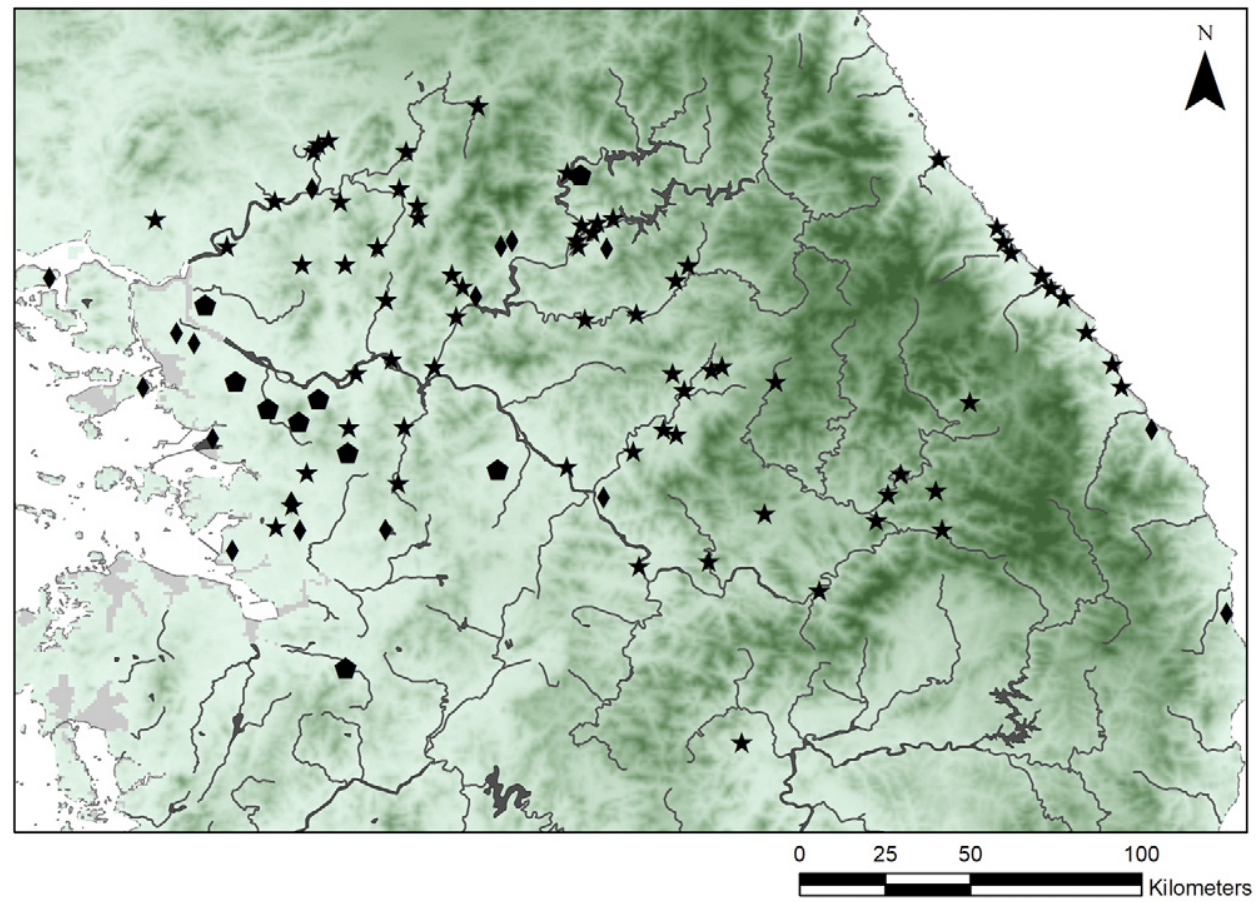

Fig. 8. Distribution of Korean Central Region sites with Plain Hard Pottery (\), Ch’ ŏl/Y Yo-shape architecture ( $)$, or both $(\star)$ (after Pak Chungguk 2012:54).

Taking Pak Sunbal as a starting point, other scholars have proposed different markers in their attempts to identify distinctions between supposed 'Han' and 'Ye' ethnic groups. Pak Chungguk (2012), while undertaking a thorough critique of the Chungdo type Culture concept, considers a wide range of archaeological elements to conclude that $y \breve{o} / c h$ ' $\breve{o l}$-shaped architecture without four central posts, a formulation covering almost the entire Central Region, is the key cultural element for identifying what he now terms "Chungdo Culture" (Fig. 8). This form contrasts with domestic architecture with four central posts, which is primarily distributed in regions south of Kyŏnggi and also on the west coast (Pak C. 2012:77). He then highlights the presence of hypocaust systems (Fig. 4) to argue that this feature marks an ethnic division between the Han in the west (Seoul-Kyŏnggi) and the Ye in the east (Kangwŏn) (Pak C. 2011) (Fig. 7-2).

Kang Inuk (2007, 2009a) and other scholars (No 2004; Sim 2007a; Yu 2006, 2009, 2014, 2015) have proposed a significant role for the material culture of the maritime Siberia region, specifically Krounovka Culture, in the formation of "Hard Plain Pottery Culture" (Ch'oe M. 2013:65-66) (Fig. 7-3). Various scholars propose different vectors of influence, ranging from mass migration (No 2004) to a gradual intermixing of migrants and adoption of culture originating in maritime Siberia because of its "adaptive" potential (Kang I. 2009a:230-234) to adoption of certain elements with limited-to-no migration (Pak C. 2016; Sim 2008). In addition to aspects of the pottery assemblage mentioned above, features such as $y \breve{o} / c h$ ' $\breve{l} l$-shaped architecture (Kang I. 2007, 2009b; No 2004) and data on similarities in subsistence economies 
(Kang I. 2009a; Subbotina 2007, 2009) have been proposed as indicators of a connection between the two regions. Such proposals clearly relate to the idea that the eastern part of the Central Region was comprised of different 'Ye' or 'Ye-maek' people, who were considered distinct from the Han people in the western part of the region. Kang Inuk (2009a) skirts the issue of the Han-Ye division by focusing on environmental adaptation when discussing the proposed Hard Plain Pottery Culture, which covers the entire Central Region. However, Kang Inuk (2008:71-73) has also proposed that these material elements characterize a wider cultural area covering the East Sea/Sea of Japan region and explicitly links this archeological culture with the Okchŏ 沃沮 [RR: Okjeo] and Eastern Ye 東濊 groups that appear in the historical records; such groups are commonly held to be 'Ye(maek)'.

Yu Unsik (2007) identifies a difference in Hard Plain Pottery rim manufacturing between the Seoul-Kyŏnggi area and Kangwŏn province, with "internally angled" and long-necked yugyŏng [RR: yugyeong] jars 有頸㪍 concentrated in the latter area (Fig. 3). He also notes that certain forms are distributed unevenly within the Central Region, with a suite of "Tumen River Pottery," similar in style and finishing methods to material found in maritime Siberia, focused in the Kangwŏn province away from the Han River basin (Yu 2006). Additionally, he notes that burnished Hard Plain Pottery is concentrated in Kangwŏn ( $\mathrm{Yu}$ 2007, 2009). Due to the regional distinctions he identifies, Yu (2014) argues for the necessity of a regional review. However, he also explicitly links these patterns to various proposals of the 'Chungdo Type Culture' model and the influence of material culture from the maritime Siberia Region, and therefore maintains an implicit assumption of a 'Ye' identity in the Central Region.

Aikens and colleagues (2009) similarly suggest that the east coast of Korea was part of an overarching long-term East Sea-Sea of Japan "oikumene" covering maritime Siberia, the east coast of the Korean peninsula, and parts of Japan. Whilst they examine long term (from the Paleolithic through early Three Kingdoms period) patterns across a much wider area, they also argue for a distinct cultural interaction area spanning the east side of the Korean peninsula (Fig. 7-3). Aikens and colleagues (2009) contrast this to the material culture in the western part of the peninsula, which they claim was more heavily influenced by ancient China. As with other models, delineations of these proposed areas are based upon formal comparisons of a number of material cultural units, including lithics, pottery, metals. Clearly their "oikumene" overlaps with Kang Inuk's (2008) proposed "cultural area," which might be considered part of the same long term trend. However, Aikens and colleagues (2009) do not use material similarities and differences to draw any conclusions regarding migration, ethnicity, or group identity.

In their examinations of regional interactions and state formation processes, Barnes (1986, 2001:27-36, 2015:317-322) and Pai (1992, 2000:207-236) also discuss the Korean Central Region during the Late Iron Age. More recent material in the English language has also primarily focused on areas where state societies emerge (see edited volume, Byington 2009). Due to broader temporal and geographic scales, specific models regarding the Central Region are not proposed and the focus on regions that later hosted state development or show the most active contact with the Chinese civilization means that the $\mathrm{Ye}$ are not discussed in depth in such studies. More specifically, understandings of Mahan's location and structure during the Late Iron Age are still taken in the context of historical texts, ancient Chinese records in particular. Thus, the Han River basin continues to be labeled as part of Mahan, thereby replicating an identification of this region with Han ethnicity. 
Other work has presented generalized models of Late Iron Age settlements, polities, or social structures (Kwŏn Oyŏng 1995; Yi Hŭijun 2000; Yi Hyunhae 2009). These schemes tend to rely heavily on historical texts for terminology and rationale, without addressing problems in the texts such as contradictory and vague passages that restrict the ability to take these records at face value. Bong W. Kang (2000a), for example, depends on such texts to suggest that warfare played a significant role in polity development due to regional under-population and the need to capture workers to produce wealth for elites. In a related study, he examines burial assemblages in relation to records of warfare, "testing" whether weapons are more prevalent in periods of recorded warfare (Kang B. 2000b). Rather than considering potential issues with the textual record (i.e., he does not examine whether weapons and armor were actually used), he identifies concordances and contradictions depending on the period and explains discrepancies in terms of chronological issues or as time lags between periods of conflict and burial of weapons (Kang B. 2000b:72-73). Other scholars have attempted to identify particular polities mentioned in the texts (e.g., "Mokchiguk 目支國 [RR: Mokjiguk]”) (Ch'oe M. 2013:87-91, 93; Ch'oe and Kim 2005:75-79) or delineate the locations or territory sizes of polities in particular areas (Kim S. 2014; Yi Hyunhae 2009). These more general studies do not reference the Ye nor discuss any ethnic division in the Central Region, but they do implicitly reproduce assumptions regarding the scope and nature of Mahan as it is commonly interpreted from the historical records.

Several authors contend that it is not possible to clearly define where the boundary between Han and Ye groups lies. Kwŏn Oyŏng (2009) argues that, while some level of regional variability exists, wooden coffin or chamber tombs can be linked to the "Han," but it remains unclear whether areas without this type of tomb or with Stone Mound Tombs can be definitively linked with the Ye. Additionally, he says that different house shapes (square, rectangular, pentagonal, hexagonal, etc.) and their entrance features ( $c h$ 'ŏl-shape, $y \breve{o}$-shape, none) show no clear exclusivity in any region, making it impossible to separate 'Han' from 'Ye' on this basis (Kwŏn Oyŏng 2010). Song Manyŏng (2010) generally concurs with this assessment, arguing that the shapes and internal features of much of the Central Region's Late Iron Age domestic architecture show no clear regularity. Other issues, such as the high relative concentration of Han Dynasty or Lelang (Kor. Nangnang)-style artefacts on both the eastern (Kim I. 2009:160-170; Pak C. 2012:78) and western (Sim 2007b) sides of the T'aebaek (RR: Taebaek) Mountains and the likely variability in the dates of the disappearance of Hard Plain Pottery (Sim 2009; Yi and Kang 2009), add further complexity to overall regional patterns.

Finally, Song Manyŏng (2003) presents an alternative meaning for Stone Mound Tombs. Using the Chinese historical documents, he notes a record of people moving from the Lelang commandery into 'Han' and 'Ye' territories during the mid-late second century. He links the rise of these monumental tombs to the growing control of certain groups over riverine trade routes within a "Han-Ye(maek) Political Community" (한예(맥)정치공동체 Han-Ye(maek) chŏngch'i kongdongch'e [RR: jeongchi gongdongche]) (see also Sim 2010). Song Manyŏng (2003:138-139) goes on to suggest that the Han River basin becomes the focus of these trade routes into the third century C.E., while Sim Chaeyŏn (2010) notes the likely influence of the "Non-Stepped Stone Mound Tombs" (mukidansik chǒksŏk ch'ong 무기 단식적석총) of the upper and middle Han River basin on early Paekche monumental tombs (Fig. 9). The name chosen for 


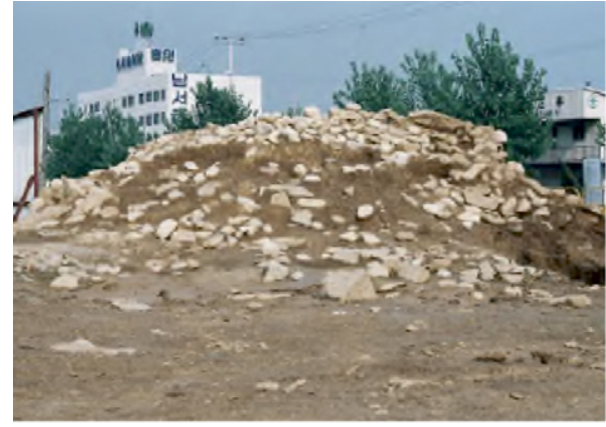

(1)

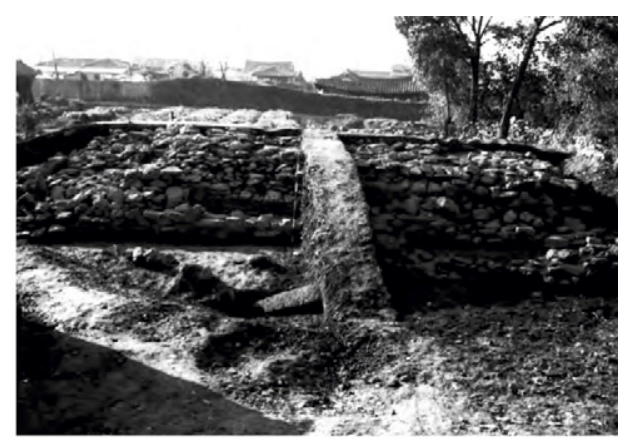

(2)

Fig. 9. Tombs from the lower Han River basin: (1) non-stepped Piled Stone and Earth Mound Tomb 즙석봉토분 (chŭpsŏk pongt'obun) (cf. Fig. 5) (reproduced with permission from Seoul Taehakkyo Pangmulgwan 2015:164, photo 20-2); (2) Stepped Tomb (reproduced with permission from Seoul Taehakkyo Pangmulgwan 2013:145, photo 21-1).

this "community" reproduces the assumption that there were two ethnic groups in the region, but these scholars raise the possibility that Stone Mound and other monumental tombs are not indicators of specific ethnicities or group identities but rather indicative of particular political and power structures during the later second century and early-mid part of the third century.

The following section discusses and evaluates key theoretical and methodological bases for the main models discussed above. I distil and examine the core logic of how these models were built to assess their suitability for describing the historical cultural situation of the Central Region during the Late Iron Age.

\section{EVALUATION OF CURRENT MODELS}

The above overview suggests that Pak Sunbal's (1996, 2001a) original proposal of a 'Chungdo type Culture' has spawned a number of competing, yet highly similar proposals of how the Korean Central Region was organized during the Late Iron Age. The majority of these other systems contrast with his original suggestion only in terms of the specific units used to define ethnic or cultural boundaries. Those scholars that link the material of Kangwŏn province with the maritime Siberian region follow a similar logic in noting similarities in form or subsistence and then drawing a connection between the cultural identities of the two areas, generally via some extent of migratory process or overlapping "archaeological cultures." This approach is also reproduced by Kwŏn Oyŏng (2009), who critiques existing models, yet retains references to particular types of types of graves as definitively "Han."

In other words, the methodologies and concept of culture are analogous. Group or ethnic identity is attached to specific pieces of material culture, the geographic distribution of said material culture is mapped, and this area is taken to be the territory of said group. Names of groups (assumed to be of an ethnic or tribal nature) from the historical texts are either starting points (for Pak S. 2001) denoting where we should expect to find certain groups or are attached to archaeological cultures once they have been described (e.g., Kang I. 2008). 
The concern with identifying cultural and ethnic areas can be seen as part of a project to trace and identify the origins, movements, and territorial extent of the historical Han ethnic group, seen as the ancestors of modern Korean people (Nelson 1993:3, 2010; Pai 2000). Such a project is therefore consistent with a prevailing paradigm that sees the main role of Korean archaeology to be that of delineating the history and tracing the origins of the modern Korea and the "Han People" (Hwang 2010:10-11). An example of the origins search is Pak Sunbal's (1993, 2004) linking the Central Region with the northwestern part of the Korean Peninsula via an account of the origins of Hard Plain Pottery with externally angled rims (Kor. oeban'gu yŏnho 外反 口緣瑴). Specifically, a connection is proposed between this pottery type of the Late Iron Age Central Region and Myŏngsa-ri (RR: Myeongsa-ri) Style Pottery of the T'aedong [RR: Taedong] River basin (modern day Pyongyang area and subsequent site of Lelang Commandery) (Fig. 1). The latter type is associated with the Ko Choson 古朝鮮 [RR: Gojoseon] Culture (Pak S. 2001a), a polity that fell to Han Dynasty China in 108 B.C.E. and still holds an important place in Korean national history. The path and history of ethnic 'Han' are therefore traced via examining Myŏngsa-ri Style Pottery with reference to an exodus of Han refugees from Ko Chosonn following its collapse.

Three core concepts and methods common to the majority of current models can be isolated from these studies: (1) a common concept of culture as "archaeological culture," which results in a checklist approach to culture and social identity; (2) a literal reading of historical texts; and (3) the assumption that ethnicity can be observed in forms of material culture. All of these logics overlap in some way, but not all are applied to building each model. For example, while the first point applies generally to Pak Sunbal's (1996, 2001a) initial suggestion of a "Chungdo type Culture," his interpretation of historical texts (and linking of archeological patterns with "ethnicity") are primarily related to the development of the model. Other authors who have used his model as a starting point have accepted the same basic assumptions regarding ethnic groups. One exception would appear to be Song Manyŏng's (2003) suggestion that Stone Mound Tombs are linked to the emergence of particular trade routes and therefore social-political development. This is a sophisticated model, yet suffers in terms of its lack of theoretical development and empirical evidence. It also remains reliant upon the historical record in terms of its explanation of process, and therefore will be dealt with more generally below.

\section{Concept of Culture}

As noted above, material-cultural elements are regarded as directly indicative of historical groups and identities. Boundaries are drawn around archaeological units such as Stone Mound Tombs, hypocaust systems, $c h$ 'ŏl/ yŏ-shaped architecture, or a combination of such features. These features are then employed to track groups through time and space as bounded entities to which the names of identities and social formations mentioned in historical texts have become attached. In Clarke's (1978:36-37) terms, culture is thereby treated as "monothetic." Only communities with the requisite cultural elements are considered legitimate members of a particular concrete group. Subsequently, communities without the identified elements are not given group membership even when there are a great number of other commonalities with the former group. Explicit theoretical bases for why particular attributes are chosen to 
reflect a particular 'archaeological culture' are often lacking. Additionally, and as highlighted in the case study here, examinations of multiple types of units often reveal an inability to draw clear boundaries (regarding this issue for the Central Region's Late Iron Age, see Kwŏn Oyŏng 2009). This forces scholars to rely upon singular elements to identify groups; such a logic is not fully Childean, however, since Childe saw that culture was polythetic (though did not use that term) (Jones 1997:17-18).

The use of binary archaeological markers, the presence or absence of which are taken to indicate the presence of a certain 'culture', fails to address the question of whether the defining unit (or units) holds the same meaning or use throughout the study area. Additionally, narrow considerations of particular cultural units leads to their being examined outside of their relations with other elements and results in a taxonomic focus on single classes and the variations within them, rather than potential relationships between or among multiple classes (Martin 2013:111-130; Zedeño 2008:373-376, 2013).

As noted above, material (Hard Plain Pottery, Paddled Patterned Pottery, stoneware, ironware) and architectural (ch'ŏl/ yŏ shaped architecture) elements were shared throughout Central Korea during the Late Iron Age. Common architectural patterns and domestic arrangements also characterize this region (Blackmore 2015). These patterns do not necessarily relate to ethnic sameness, but they do demonstrate fundamental uniformity in traditions of living. Such sameness is erased by intensive focus on the formal aspects of particular archaeological units. Thus, the check-list approach to culture, based on examining a limited number of archaeological attributes, can only result in somewhat superficial analyses and different definitions of cultural areas depending upon the specific units an author chooses to highlight.

Furthermore, research frameworks focused on the origins of a selected material assemblage do not cope well with cases where multiple archaeological elements have multiple 'origins'. For example, models concerning the origins of the Hard Plain Pottery tradition have focused on processes of diffusion or migration from northeast China and the northwestern part of the Korean Peninsula (Pak S. 1993, 1996, 2004) or from maritime Siberia and the Tumen River basin (Kang I. 2007, 2009a; No 2004; Yu 2006, 2007). However, as noted by Sim Chaeyŏn (2011), neither of these options alone are acceptable. The former cannot explain the lack of Triangular Clay Stripe Pottery 三角形粘土帶土器 (Kor. samgakhyŏng chŏmt'odae to'gi [RR: samgakhyeong jeomtodaetogi]) in Kangwŏn, while the latter cannot fully explain what prompted migration or the uptake of new material culture, nor how and why the migrants adopted Paddled Patterned Pottery (Sim 2008). Associated material culture (i.e., Paddled Patterned Pottery, ch'o $l / \gamma \breve{o}$-shaped architecture, hypocaust systems) would also appear to have disparate origins, potentially from maritime Siberia (Aikens et al. 2009; Kang I. 2007, 2009a; No 2004; Yu 2006, 2007), Lelang Commandery (Pak C. 2011; Pak S. 2001b), Warring States Period northeast China (Ch'oe P. 1998; Kim Changsŏk 2009, 2012), and the southwestern part of the Korean Peninsula (Kim Changsŏk 2009, 2012, 2014). There was also likely to have been local development alongside the adoptions of these forms of material culture (Sim 2011). Using a monothetic framework focused upon individual units and their 'movements', rather than the dynamic and interrelated whole, would make it very difficult to untangle these complex relations and processes.

This section has described some of the methodological and theoretical commonalities of many archaeological studies in Korea. As already mentioned, most 
scholarly work on the Late Iron Age in the Central Region are rooted in Pak Sunbal's (1996, 2001a) "Chungdo type Culture" and the assumptions of an ethnic division between 'Han' and 'Ye'. Given the importance of this model, it is appropriate to focus on Chungdo type Culture in the next two subsections.

\section{Understandings of Historical Texts}

According to Ju (2009: 117), many Korean archaeologists implicitly or explicitly keep the historical record in mind when formulating their research questions and models. He notes that explanations for change and patterns in the archaeological material are very often made with reference to these texts (Kim Changsŏk 2012; Nelson 2010). This situation is conspicuous in the case of Chungdo type Culture and the presumed Han-Ye ethnic division in the Central Region. Even in work focused on the Neolithic, which is far removed from periods covered by the historical records, scholars remain concerned to highlight broad assemblage groups, even though they tend to couch their analyses in terms of general "group identities" rather than labeling specific tribes or ethnicities (Im 2012). They also tend to focus more on issues of subsistence for the Neolithic period than for the Iron Age (An 2005; Lee 2011).

In order to build the Chungdo type Culture model, Pak Sunbal (1996, 2001a) refers primarily to the Samguk sagi, a text given historical primacy by Kim Wónyong (1967). This text, written in the twelfth century by an official from the Koryŏ (RR: Goryeo) kingdom, purports to give a history of three early kingdoms on the Korean peninsula (Paekche 百濟, Silla 新羅, Koguryŏ 高句麗 [RR: Goguryeo]). Its record of "Ye (maek)" raiders coming from the north and east to invade Paekche orient Pak Sunbal's subsequent model. He and other scholars then expect to find specific material cultural marker(s) in the areas north and east of what will become the early Paekche centre, which emerged in the Han River basin sometime in the late third to fourth century (Best 2006:41; Kwŏn Oyŏng 2008; Pak S. 2001a:209-210).

Ancient Chinese texts also inform the Chungdo type Culture model, primarily the third century Sanguozhi 三國志 (Records of the Three Kingdoms). An assumption is made that the "statelet" (Kor. soguk 小國) of Paekche 伯濟 appearing in the Sanguozhi account of Mahan was contiguous in terms of group identity and geographical location with the later state of Paekche. As a member of the Mahan Confederacy, the ethnic identity of the population of the Paekche statelet is implicitly taken by Pak Sunbal (1996, 2001a) to be 'Han' (in opposition to 'Ye'). As noted above, other scholars have followed his original suggestion, simply by identifying the Han and Ye based on different criteria. Ethnicity cannot be treated as an inflexible identity, however, which makes it difficult to simply assume that the situation of the Paekche soguk named in the Chinese accounts of the mid-late third century would have reflected prevailing state of affairs throughout the entire Late Iron Age.

Pak Sunbal and like scholars also assume that the Mahan Confederacy was a closed ethnic structure that excluded non-Han. However, this does not necessarily hold. The Mahan accounts in Chinese texts only represent partial and external views of this society. Details on the inner workings of constituent Mahan groups and the relations between these groups are vague. Other than labeling Mahan as one of the three "kinds" of Han in the Sanguozhi account - " "There are three kinds of Han, the first is called Mahan, the second is called Chinhan, the third is called Pyŏnhan [ 有三種, 一曰馬韓, 二曰辰韓, 
三曰弁韓]” (Sanguozhi Chapter 30, quoted by Byington 2009:133) — information regarding individual statelets is largely absent. ${ }^{1}$ A list of 55 statelets constituting Mahan represents a snapshot in time (see Sanguozhi Chapter 30 in Byington 2009:134), but whether these statelets were always part of Mahan and whether this situation can be projected back in time from the mid-late third century remains unclear. Indeed, Paekche origin stories from the Samguk sagi stress the non-local origins of the kingdom's founders. These stories claim Paekche descended from Koguryŏ or Puyŏ [RR: Buyeo] polities, the former of which had an affinity with the historical Ye (Kwŏn Ojung 2010). The veracity and claimed time-frame (late first century B.C.E.) of these origin accounts are also highly debatable (Best 2006; Gardiner 1969:43-47). Such details should prompt a critical view rather than taking the Sanguozhi accounts as read. Scholars should also not take it for granted that Mahan is an ethnic construct rather than a political grouping.

Conceptions of the 'Ye' likewise fail to take into account the history of how this label was used in Chinese records over time. Many of the Samguk sagi references Pak Sunbal $(1996,2001 a)$ used to build the Chungdo type Culture model come from sections purporting to date from the 2 nd century B.C.E. -1 st century C.E., locating the 'Ye' to the north and north-east of the lower Han River area (see above). Yet seeing this section of the record as reliable is highly problematic (Best 2006; Ju 2009), and is therefore unlikely to hold concrete information regarding the Late Iron Age. In the Chinese histories, the terms 'Ye' or 'Ye-maek' are fluidly applied and are not used to indicate eastern or east coast groups such as Okchǒ 沃沮 or Eastern Ye 東濊 until the mid-third century (Kwŏn Ojung 2010). Equally, the 'Ye(-maek)' are never mentioned in relation to Mahan in any of the of the Chinese records. The Ye are only said to be north of Chinhan (“濊南與辰韓”; Sanguozhi: Chapter 30 [濊傳 Account of $\mathrm{Ye}]$ ), which was a separate group of polities located in the southeast peninsula. ${ }^{2}$ Finally, certain categories such as "Malgal" mentioned in the early Annals of Paekche in the Samguk sagi must reference later Chinese texts because such terms do not appear in records until the seventh century (Best 2006:38-39). Such issues add weight to the conclusion that the early Paekche Annals are highly unlikely to stretch back as far as they purport to, and are far more likely to be related to the end of the Iron Age or following Three Kingdoms Period, that is, after around C.E. 300. This situation exposes a 200 to 300 year lacuna in the textual data that covers almost all of the Late Iron Age and indicates that Han and Ye may well not have been salient categories in the Central Region.

Assuming the events described in the Samguk sagi regarding early Paekche and the Ye(maek) are not simply legend or myth, the records mentioning 'Ye' or 'Malgal' raids on Paekche may have described events of the third or fourth centuries C.E. rather than the first century B.C.E. This probability is suggested by Best (2006:41), who argues that the twelfth century compilers of early Paekche history (in the same text) extended this polity's interactions with Silla back in time to the first century C.E. rather than the more plausible fourth century C.E. This concurs with the same period when the 'Ye' label began to be applied to groups on the east coast of the Korean peninsula in Chinese texts, providing further circumstantial evidence that these records have been projected backwards in time. Therefore, even if the Samguk sagi is an accurate portrayal of the Korean Central Region during the mid-third through fourth centuries, we cannot take for granted that this state of affairs would have applied throughout the Late Iron Age. 


\section{Concepts of Ethnicity}

Scholars of the Korean Central Region's Late Iron Age explicitly treat groups named in historical texts in ethnic terms. For example, they refer to the Ye(kye) and Han as “tribes” (Kor. chongjok 種族 [RR: jongjok]) (Pak S. 2001a:79-80) while leaving implicit or failing to define the meaning of 'tribe' or ethnic group. The prevailing Culture-Historical approach not only stresses the importance of identifying bounded archaeological cultures and generating a history of 'Korean' ethnicity, it makes it appear natural to either attach historical group names to identified archaeological cultures or start with these names and then search for archaeological patterns that fit the texts. In this view, ethnicity is seen as stable and directly related to a fixed set of values and practices which can be identified by their material correlates (Lucy 2005; Upton 1996:1-2).

Several scholars have questioned the ability of archaeologists to securely attach ethnicity or political groupings to particular material-cultural units or groups of units (Gosselain 1998; Jones 1997; Kwŏn Oyŏng 2010; Lucy 2005; MacEachern 1998; MacSweeney 2009; Upton 1996). Making such connections is difficult or impossible, first because of the complexity and fluidity of ethnic identity and, second because the types of archaeological units or groupings that archaeologists can identify or pay attention to do not necessarily relate to any specific past group identities (Clarke 1978; Gosselain 2000, 2008; Shennan 1989).

In the case of the Late Iron Age of the Central Region, it is difficult to justify locating "historical" groups within the archaeological record because available information regarding these groups does not directly relate to the self-identities of the people in the region at this time. Kwŏn Oyŏng (2010:15) suggests group or ethnic identities have three factors: (1) self-identity; (2) the identity ascribed to an individual by others; and (3) "real ethnic identity (실제 종족 정체성 silche chongjok chŏngch'esŏng [RR: silje jongjok jeongcheseong])," perhaps better expressed as genealogical ethnicity. Following Kwŏn Oyŏng (2010), I argue that, other than some limited and vague locational information provided in historical texts, only the Chinese group labels such as 'Han', 'Ye', and 'Maek' are available to present day scholars. These labels clearly represent an external view and so do not necessarily reflect the real identities of any groups on the Korean Peninsula. Similarly, the Han 漢 Chinese authorities of the Lelang commandery did not take into account local history and the variety of ethnic identities (including of those native to the peninsula and older generations of Chinese immigrants), but instead called everyone in the area " $\mathrm{Hu}$ 胡" in opposition to new immigrants coming from Han Dynasty lands (Kim B. 2013:258-269). Thus, for the main period under discussion here, Kwŏn Oyŏng's (2010) factors 1 and 3 are absent, and only a single very particular perspective on factor 2 is available for present day archaeologists to reference.

Even if the labels found in the Sanguozhi and Samguk sagi are accepted as representing certain historic groups, uncritically applying these names onto archaeological patterns is difficult to justify. Ethnicity is dynamic and changeable, being a route for self-identification and the identification of others (Jones 1997, 2007; Shennan 1989:14; Upton 1996). Ethnic identity is also just one of various types of social identity and is unlikely to be wholly independent of gender, religion, social class, and the like (Curta 2007:175-177; Hackenbeck 2007; Meskell 2007:24-28). Furthermore, ethnicity is not necessarily required for group identity to form (MacSweeney 2009). 
These issues therefore complicate Kwŏn Oyŏng's (2010) factors 1 and 2, whereby both self-identity and the labels or expectations imposed by outsiders have the potential to become fluid and unfixed. Ethnicity is constantly under construction and negotiated between group members and with outsiders (Jones 1997, 2007). The maintenance and reproduction of these categories is, for the most part, active, being based on social practice and the use contexts of material-culture (Curta 2007; Gosselain 2000, 2008, 2011; Jones 2007; Lucy 2005; MacSweeney 2009). As highlighted by the changing meaning of 'Ye-maek,' an assumption of long-term stability in 'Han 韓' identity, or what eventually becomes 'Ye' identity, has a weak basis.

\section{DISCUSSION}

The problems discussed above mean that the predominant models currently characterizing the Late Iron Age of the Korean Central Region are highly unlikely to accurately reflect the past reality. These models are almost exclusively based upon only one or a handful of formal aspects of the archaeological material, while implicitly assuming that these aspects can be securely linked to past 'peoples', and then explicitly attaching such narrow assemblages with named groups in the historical record. Not only is that base assumption hard to justify theoretically, but the historical records used to justify the models are highly likely to be partial, insecurely dated, or biased. Equally, even if the ethnic group names that appear in the historical records are considered to have credibility, the names represent an almost wholly external view on such groups and therefore do not directly relate to any internal social categories of the Korean Peninsula during this period.

The case study and analysis presented here highlights the limits of what we can say about the distribution patterns of archaeological assemblages and the caution needed regarding the application of applying the names of groups seen in the historical texts. A critical examination of what the terms may indicate and how they came to be written down (especially when applied by actors external in space or time), how these names developed through time or have been applied historically, and an explicit theoretical justification for why particular material correlates indicate group identity and not other contingencies, is essential. Hypothesizing locations for certain groups named in the texts and then identifying singular attributes of the archaeological material that fit the expected pattern constitutes circular logic; when the premise is already assumed to be true, the vast majority of evidence becomes discounted.

These critiques apply to the majority of models of Late Iron Age Central Korea, but perhaps most importantly to Pak Sunbal's (1996, 2001a) concept of "Chungdo type Culture." The importance and influence of this particular model cannot be overstated. The setting out of two separate ethnic areas through the "archaeological culture" concept, along with the reliance on categories within foreign or secondary-tertiary historical records, not only laid out a methodology, but produced a model that has subsequently framed debates, research questions, and conceivable explanations for archaeological patterns. By fixing the Han River basin within the Mahan entity (as earlier scholars had also done, see Barnes 1986; Pai 1992), this framing has obscured potentially significant patterns of interaction within the Central Region.

While assumptions of a clear Han-Ye ethnic division in the Central Region have become solidified and applied to the entirety of the Late Iron Age, a flaw in the Chungdo type Culture model undermines the model on its own terms. The 
archaeological unit taken to mark this ethnic distinction, Stone Mound Tombs, did not exist for the vast majority of the period. Recent work has reappraised the chronology of Stone Mound Tombs, dating them to the mid-latter part of the third century (Sim 2010; Song 2003) or to the Hansong Paekche period (post C.E. 300) (Pak C. 2012). Thus, there is no extant cultural unit defining the proposed 'Han-Ye' division between the first century B.C.E. and the early-mid third century C.E. This situation again mirrors the point above regarding the third century shift in meaning of the term 'Ye-maek'. There is no reason to regard these tombs as ethnic or group indicators, and the probability that such tombs are indicative of particular political and power structures arising during the later second century and early-mid third century is significant.

The implications of this realization are substantial. If we can put the Han-Ye ethnic distinction aside, and if we can accept that material forms and their distributions indicate areas of ongoing interaction networks, it would appear that significant interaction networks characterize the entire Korean Central Region, indexed by the widespread distribution of common pottery types and architectural units. This pattern contrasts with the situation between the Han River basin and southwestern Korea (along with the rest of the south), areas which have both been labeled as part of the Mahan Confederacy. Neither Hard Plain Pottery nor the ch'ŏl/ yŏ style of architecture penetrate into southwestern Korea, suggesting some form of boundary existed, be it social, geographical, or technical (Fig. 8). We can therefore highlight a relatively longstanding distinction between the area where the state of Paekche first emerges and rest of Mahan, the reasons for which require elucidation and need to be taken into account in any discussion of the emergence of Paekche.

This pattern also has wider repercussions. During the Iron Age, the Korean Central Region appears to exist within a significant and dynamic interaction network with the maritime Siberia region. This network does not just exist on the eastern side of the peninsula (as per Aikens et al. 2009; Kang I. 2008) but penetrates into the Han River basin. These patterns of interaction thus overlap with the proposed "Yellow Sea Interaction Sphere" and influence of the Lelang commandery (Barnes 2015:309-330; Pai 1992). Any discussion of the Central Region (i.e., of Mahan, Ye, and the rise of Paekche) therefore needs to take these links into account.

In order to fully understand the dynamics of the Korean Late Iron Age, future work should consider more than the distributions of material forms or assemblages. The concept of culture must move beyond artifacts to consider patterns of use and common ways of living, shared ways of "knowing how to go on" (Barrett 1994:134; also see Martin 2013:121-127). At some point in the past, the (now archaeological) material provided an "architecture" for particular ways of life (Barrett 2001:151-152). The same 'architecture' is likely to be viewed and used differently by individuals that have developed in different cultural contexts. Commonalities in technical or technological styles can reveal social boundaries and shared ways of living or viewing the world; such styles constitute ways of making, genealogies of learning, or arrangements of architectural space, among other things (Gosselain 2008; Stark et al. 1998). Although we may be limited in the ability to know what kind of identities such styles may represent, patterns within an assemblage and their distributions on sites or throughout time and space allow the identification of cultural institutions. In other words, particular social institutions (e.g., burial rites, social hierarchy, spatial organization of settlements) crystalize materially in particular ways (Kristiansen 2011; Kristiansen and 
Larsson 2005:4-31). The reproduction of these patterns in time and space highlights a shared way of moving through the world. Examining the adoption and abandonment of particular types of social institutions, and any modifications made along the way, provides far more richness and grounding in terms of what the human subjects under investigation were actually doing.

While such work remains to be done with regard to the Korean material discussed here, there is now a plethora of new archaeological data from across the southern part of the Korean peninsula. Even though the distribution of sites and materials discovered since the later 1990s tends to follow modern development concerns (Bale 2008; Shoda 2008), detailed chronologies and descriptions of such data is available. Much work on production processes (particularly of pottery) and exchange has also been carried out. There is therefore a wide scope for future work of all colors, covering topics from local or regional issues of identity and lifeways to state formation and regional interchange.

\section{CONCLUSIONS}

The Chungdo type Culture model has dominated discourse on the Late Iron Age in Central Korea. This model has prompted many scholars to accept the assumption that a clear ethnic division existed throughout the period, between the 'Han' (attached to Mahan) in the west and the Ye in the east. Research questions and interpretations have subsequently been formed from this base, and critiques have revolved around redefining the archaeological elements that mark each ethnic or group boundary. However, the justifications for the assumption that these identities were distinct and practiced categories during this period are highly contestable. In terms of archaeological theory, such models assume a direct correlation between material elements and group identity and thus underestimate the complexities of how such identities were expressed through material culture. Furthermore, the term 'Ye' as a category was applied by external actors in historical texts; it did not come to signify populations near the Central Region until the third century and later. The archaeological markers used to justify the existence of a "Chungdo type Culture" can also be dated to the third through fourth centuries, which suggests that a later situation was projected back across several centuries; this undermines the Chungdo type Culture model on its own terms.

This situation brings into view two issues that have thus far been obscured by the view that the Central Region was clearly split between two groups. One is that the Han River basin, where the state of Paekche purportedly emerges out of Mahan, has far more material culture in common with the rest of the Central Region than with the southwestern part of the peninsula (Song 2003:138). Any examination of Paekche's emergence must take this into consideration; an examination of what social boundaries existed between the Han River basin and the southwest is very much needed. The second issue is that communities in the Central Region are clearly part of an influential interaction network with the maritime Siberia/Tumen River region. The role of this interaction sphere in the development of the Central Region's Late Iron Age needs to be elucidated in conjunction with the well-documented influence of the Lelang commandery and Han Dynasty China.

Thanks to a large database of recent work and excavations in Korea, there is now a great deal of material and potential for future synthesis. Future work on this region may find it fruitful to move past established histories and the use of index fossils to instead focus on identifying commonalities in the use contexts of material culture in order to 
identify shared institutions and ways of life. In this way, a richer understanding of the dynamics of the Late Iron Age could be built. That understanding will positively impact how we address issues of cultural exchange and state formation in the wider region.

\section{ACKNOWLEDGMENTS}

I am very grateful to the Seoul National University Global Scholarship scheme, which allowed this work to come about. I must also thank Prof. Seonbok Lee, Prof. Jongil Kim, Dr. Junjeong Lee, Dr. Jangsuk Kim, Dr. Ilhong Ko, and Junkyu Kim, all of whom gave essential feedback and support. Many thanks likewise go to the editors and two anonymous reviewers, whose comments helped my thinking and the outcome here immensely.

\section{NOTES}

1. See also text of Sanguozhi available on Chinese Text Project (website), 2006-2018, at ctext.org/text. pl?node $=603360 \&$ if $=$ en.

2. See text of Sanguozhi on Chinese Text Project (website), 2006-2018, at ctext.org/text.pl?node= 603356\&if $=$ en.

3. Map made with Natural Earth 2009-2018, a public domain dataset available at www.naturalearthdata. com.

\section{REFERENCES CITED}

Aikens, C. Melvin, Irina S. Zhushchikhovskaya, and Song Nai Rhee

2009 Environment, ecology, and interaction in Japan, Korea and the Russian Far East. Asian Perspectives 48(2):207-248.

AN SŭNGMo 안승모 [AHN Sung Mo]

2005 Han'guk nambu chibang sinsŏkki sidae nonggyŏng yŏn'gu ŭi hyŏnsang kwa kwaje 韓國 南部 地方 新石器時代 農耕 研究의 現狀과 課題 [Review of the Neolithic agriculture in Southern Korea]. Han'guk sinsŏkki yŏn'gu 한국신석기연구 10:7-25.

Bale, Martin T.

2008 Archaeological heritage management in South Korea: The Nam River Dam Project, in Early Korea: Reconsidering Early Korean History Through Archaeology: 213-233, ed. M. Byington. Seoul: Early Korea Project, Korea Institute, Harvard University.

2014 Kyŏngje mani anida: mumun sidae chŏn'gi esŏ chunggi roŭi ihaeng e taehan sirhŏmjŏk, pip'anjŏk kŏmt'o 경제만이 아니다 - 무문시대 전기에서 중기로의 이행에 대한 실험석•비판적 검토 [It's not just the economy: A critical pilot study on the transition from the Early to Middle Mumun Period], in Han'guk kogohak ǔi sinjip'yŏng 한국고고학의 신지평 [New Prospects in Korean Archaeology]. Proceedings of the $38^{\text {th }}$ National Conference of the Korean Archaeological Society. Seoul: Han'guk Kogo Hakhoe.

Barnes, Gina L.

1986 Jiehao, tonghao: Peer relations in East Asia, in Peer Polity Interaction and Sociopolitical Change: 79-91, ed. C. Renfrew and J. F. Cherry. Cambridge: Cambridge University Press.

2001 State Formation in Korea: Historical and Archaeological Perspectives. Richmond, Surrey: Curzon.

2015 Archaeology of East Asia: The Rise of Civilization in China, Korea and Japan. Oxford: Oxbow.

BARRETT, JOHN C.

1994 Fragments from Antiquity: An Archaeology of Social Life in Britain, 2900-1200 BC. Oxford: Blackwell.

2001 Agency, the duality of structure, and the problem of the archaeological record, in Archaeological Theory Today: 141-164, ed. I. Hodder. Malden, MA: Polity Press. 
BEST, JONATHAN

2006 A History of the Early Korean Kingdom of Paekche. Cambridge, MA: Harvard University Asia Center.

BINFORD, LEWIS R.

1962 Archaeology as anthropology. American Antiquity 28(2):217-225.

1965 Archaeological systematics and the study of culture process. American Antiquity 31(2):203-210.

BlaCKMORE, HaRi

2015 Wŏn'samguk sidae chungbu chibang e kwanhan model tŭl ŭe pip'an chŏk chekŏmt'o 원삼국시대 중부지방에 관한 모델들의 비판적 재검토 [A Critical Review of the Primary Models Related to the Proto-Three Kingdoms Period in Korea's Central Region]. MA Thesis. Seoul National University, Seoul.

Byington, MARK

2009a Early Korea 2: The Samhan Period in Korean History, ed. Mark Byington. Seoul: Early Korea Project, Korea Institute, Harvard University.

2009b Sangouzhi: The Account of the Han, in Early Korea 2: The Samhan Period in Korean History: 132-152, ed. M. Byington. Seoul: Early Korea Project, Korea Institute, Harvard University.

Childe, V. Gordon

1929 The Danube in Prehistory. Oxford: Clarendon Press.

1933 Races, peoples and cultures in Prehistoric Europe. History 18(71):193-203.

Ch'oe Mongnyong 최몽룡 [Choi Mong-Lyong]

2013 Mahan: yŏn'gu hyŏnhwang kwa kwaje 마한-연구 현황과 과제 [A study of Mahan in association with archaeological and historical context]. Mahan-Paekche munhwa 마한-백제 문화 22:57-114.

Ch'oe Mongnyong 최몽룡 [Choi Mong-Lyong], And Kim KyŎngt'AeK 김경택 [Kim Gyong-TaEK]

2005 Hansŏng sidae Paekche wa Mahan 한성시대 백제와 마한 [Hanseong Period Baekje and Mahan]. Seoul: Churyusŏng Ch'ulp'ansa.

Ch'Oe PyŎNGHYǑN 최병현 [CHOI BYunghyun]

1998 Wŏnsamguk t'ogi ŭi kyet'ong kwa sŏnggyŏk 원삼국토기의 계통과 성격 [The genealogy and character of Proto-Three Kingdoms period pottery]. Han'guk kogo hakpo 韓國考古學報 38:105-145.

CH'OE SŎNGNAK 최성락 [CHOI SUNG RAK]

2005 Kogohak immun 고고학 입문 [Introduction to Archaeology]. Seoul: Hagyŏn Munhwasa.

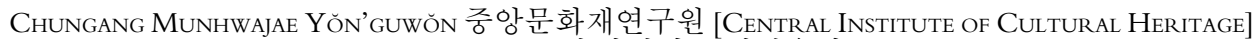

2014 P'och'ŏn Sajŏng-ni moraenae yujŏk 포천 사정리 모래내유적 [The Site by an Ephemeral Stream at Sajeong-ri, Pocheon]. Sŏngnam: Chungang Munhwajae Yŏn'guwŏn.

Clarke, David

1978 Analytical Archaeology, $2^{\text {nd }}$ ed., rev. B. Chapman. London: Methuen \& Co. Ltd.

Curta, Florin

2007 Some remarks on ethnicity in medieval archaeology. Early Medieval Europe 15(2):159-185.

Gardiner, K.H.J.

1969 The Early History of Korea: The Historical Development of the Peninsula up to the Introduction of Buddhism in the Fourth Century A.D. Canberra: Centre of Oriental Studies, Australia National University Press.

Gosselain, Olivier P.

1998 Social and technical identity in a clay crystal ball, in The Archaeology of Social Boundaries: 78-106, ed. M. Stark. Washington: Smithsonian Institution Press.

2000 Materializing identities: An African perspective. Journal of Archaeological Method and Theory 7(3):187-217.

2008 Mother Bella was not a Bella: Inherited and transformed traditions in Southwestern Niger, in Cultural Transmission and Material Culture: Breaking down Boundaries: 150-177, ed. M. Stark, B. Bowser, and L. Horne. Tucson: University of Arizona Press.

2011 Fine if I do, fine if I don't: Dynamics of technical knowledge in Sub-Saharan Africa, in Investigating Archaeological Cultures: 211-227, ed. B. W. Roberts and M. Vander Linden. New York: Springer. 
Hakenbeck, Susanne E.

2007 Situational ethnicity and nested identities: New approaches to an old problem. Anglo-Saxon Studies in Archaeology and History 14:19-27.

HODDER, IAN

1982 Symbols in Action: Ethnoarchaeological Studies of Material Culture. Cambridge: Cambridge University Press.

Hwang, Kyung MoOn

2010 A History of Korea. Basingstoke: Palgrave Macmillan.

IM SANGT'AeK 임상택 [Lim SANG TAEK]

2012 Tong-namhaean chiyŏk ŭi sinsŏkki sidae chogi t'ogi yangsik 동-남해안 지역의 신석기시대 조기 토기 양식 [Pottery styles and their implication: Initial phase of Neolithic period in eastern and southern coast of Korea]. Han'guk sinsǒkki yŏn'gu 한국신석기연구 24:1-30.

JONES, SiÂN

1997 The Archaeology of Ethnicity: Constructing Identities in the Past and Present. London:: Routledge.

2007 Discourses of identity in the interpretation of the past, in The Archaeology of Identities: A Reader: 44-58, ed. T. Insoll. London: Routledge.

Ju, BO DON

2009 Problems concerning the basic historical documents related to the Samhan, in Early Korea (vol.

2): The Samhan Period in Korean History: 95-122, ed. M. Byington. Seoul: Early Korea Project, Korea Institute, Harvard University.

KANG, BONG W.

$2000 a$ A reconsideration of population pressure and warfare: A protohistoric Korean case. Current Anthropology 41(5):873-881.

$2000 \mathrm{~b}$ A test of increasing warfare in the Samguk sagi against the archaeological remains in Yongnam, South Korea. Journal of East Asian Archaeology 2(3):139-197.

KANG INUK 강인욱 [KANG IN-UK]

2007 Yŏnhaeju ch'ogi ch'ŏlgi sidae K'ŭrounop'ŭk'a munhwa ŭi hwaksan kwa chŏnp'a 연해주 초기철기시대 크로우노프카 문화의 확산과 전파 [The spread and diffusion of Krounovka culture during the Early Iron Age of Maritime Siberia], in Kukka hyŏngsŏng e taehan kogohakchŏk chopkŭn 국가 형성에 대한 고고학적 접근 [Archaeological Approaches to State Formation]. Proceedings of the $31^{\text {st }}$ National Conference of the Korean Archaeological Society. Seoul: Han'guk Kogo Hakhoe.

2008 Tongasia kogohak-kodaesa yŏn'gu sok esŏ Okchŏ munhwa ŭi wich’i 동아시아 고고학•고대사 연구 속에서 옥저문화의 위치 [The place of Okjeo in East Asian archaeological and ancient history research], in Kogohak ŭro pon Okchŏ munhwa 고고학으로 본 옥저문화 [Okjeo Culture seen through Archaeology]: 18-82, ed. Kang Inuk. Seoul: Tongbuga Yŏksa Chaedan.

2009a Yŏnhaeju ch'ogi ch'ŏlgi sidae K'ŭrounop'ŭk'a munhwa ŭi hwaksan kwa chŏnp'a 연해주 초기철기시대 크로우노프카 문화의 확산과 전파 [The spread and diffusion of Krounovka culture during the Early Iron Age of Maritime Siberia], in Ch'ŏlgi sidae Han'guk kwa Yŏnhaeju 철기시대 한국과 연해주 [Korea and Maritime Siberia in the Iron Age]: 203-248, ed. Hwandonghae Kogohak Yŏn'guhoe 환동해고고학연구회 [Pan-East Sea Archaeological Research Institute]. Seoul: Churyusŏng Ch'ulp'ansa.

$2009 b$ Hwandonghae sŏnsa munhwagwan ŭi sŏlchŏng kwa pun'gi 환동해 선사 문화관의 설정과 분기 [Pan-eastern sea prehistorical cultural area: New perspectives on the ancient interactions between Korean and Primorye]. Tongbuga munhwa yŏn'gu 동북아문화연구 19:429-450.

KIM, BYUNG-JOON

2013 Lelang Commandery and Han China's commandery-based rule, in The Han Commanderies in Early Korean History: 249-284, ed. M. Byington. Cambridge, MA: Korea Institute, Harvard University.

KIM CHANGSŎK 김장석 [KIM JANGSUK]

2009 Hosŏ wa sŏbu Honam chiyŏk ch'ogi ch'ŏlgi-Wŏnsamguk sidae p'yŏnnyŏn e taehayŏ 호서와 서부호남지역 초기철기-원삼국시대 편년에 대하여 [On the chronology of the Early Iron Age and Proto Three Kingdom Period in Hoseo and Western Honam areas]. Honam kogo hakpo 湖南考古學報 33:45-69. 
2012 Namhan chiyŏk changnanhyŏng t'ogi ŭi tŭngjang kwa hwaksan 남한지역 장란형토기의 등장과 확산 [Appearance and spread of "Jangran-hyung jars" in South Korea]. Kogohak 고고학 11(3):5-49.

2014 Ch'wisa yonggi rŭl t'onghae pon chungbu chiyŏk Wŏnsamguk sidae p'yŏnnyŏn 취사용기를 통해 본 중부지역 원삼국시대 편년 [The chronology of the Proto-Three Kingdoms Period as seen through cooking vessels], in Chaengjŏm: Chungbu chiyŏk Wŏnsamguk sidae-Hansŏng Paekchegi mulchil munhwa p'yŏnnyŏn 쟁점: 중부지역 원삼국시 대 한성백제기 물질문화 편년 [Issues: Chronology of Proto-Three Kingdoms-Hanseong Baekje Period Material Culture]: 5-30. $11^{\text {th }}$ Maesan Memorial Lecture. Seoul: Sungsil Taehakkyo Han'guk Kidokkyo Pangmulgwan.

Kim ChangsŏK 김장석 [KIm Jangsuk], AND KIm Chun'Gyu 김준규 [KIm Junkyu]

2016 Pangsasŏng t'anso yŏndae ro pon Wŏnsamguk sidae - Samguk sidae t'ogi p'yŏnnyŏn: Chungbu, Hosŏ, Chŏnbuk chiyŏk ŭl chungsim ŭro 방사성탄소연대로 본 원삼국시대-삼국시대 토기편년: 충부, 호서, 전북지역을 중심으로 [Radiocarbon dates and pottery chronology of the Proto-Three Kingdoms and Three Kingdoms periods: Central, Hoseo, and Jeonbuk areas of Korea]. Han'guk kogo hakpo 韓國考古學報 100:46-85.

KIM CHONGIL 김종일 [KIM JONG-IL]

2008 Kogohak charyo ŭi yŏksahakchŏk haesŏk e taehan pip'anjŏk koch'al 고고학 자료의 역사학적 해석에 대한 비판적 고찰 [A critical review on historical understanding of archaeological data]. Han'guk kodaesa yŏn'gu 한국고대사연구 52:91-116.

KIM ILGYu 김일규 [KIM IL-KYU]

2009 Kap'yŏng Taesŏng-ni yujŏk ŭi Wŏnsamguk sidae chŏn'gi ch'wirak 가평 대성리유적의 원삼국시대 전기 취락 [Earlier Proto-Three Kingdoms period settlement of the Gapyeong Daeseong-ri site], in Kap'yŏng Taesŏng-ni yujŏk 가평 대성리유적 [Gapyeong Daeseong-ri Site], Academic Investigation Report 103: 163-170. Suwŏn: Kyŏnggi Munhwajae Yŏn'guwŏn.

KIM, MINGOO

2008 Multivocality, multifaceted voices, and Korean archaeology, in Evaluating Multiple Narratives: 118-137, ed. J. Habu, C. Fawcett, and J. M. Matsunaga. New York: Springer.

KIM SŭNGOK 김승옥 [KIM SEUNG-OG]

2014 Ch'wirak ŭro pon Chŏnnam chiyŏk Mahan sahoe ŭi kujo wa sŏnggyŏk 취락으로 본 전남지역 마한 사회의 구조와 성격 [Structure and characteristics of Jeonnam region's Mahan society through an analysis of settlements]. Paekche hakpo 百濟學報 11:33-72.

KIM WŎNYONG 金元龍 [KIM WON-YONG]

1967 Samguk sidae ŭi kaesi e kwanhan ilgoch'al 삼국시대의 개시에 관한 일고찰 [A study on the beginning of the Three Kingdoms Period]. Tonga munhwa 동아문화 7:1-33.

1986 Han'guk kogohak kaesŏl 한국고고학개설 [Introduction to Korean Archaeology] (3 ${ }^{\text {rd }}$ ed.). Seoul: Ilchisa.

Kristiansen, Kristian

2011 Constructing social and cultural identities in the Bronze Age, in Investigating Archaeological Cultures: 201-210, ed. B. W. Roberts and M. Vander Linden. New York: Springer.

Kristiansen, Kristian, and Thomas B. Larsson

2005 The Rise of Bronze Age Society: Travels, Transmissions and Transformations. Cambridge, UK: Cambridge University Press.

KwŎN OJUnG 권오중 [KwON O-Jung]

2010 Chŏm kwa sŏn ŭi kodaesa: Chungguk tongbuk 'Yemaek' ŭi kyŏngu 鮎과 線의 고대사-중국 동북 '예맥'의 경우 [An ancient history of point and line: A case of Yemaek in east-northern China]. Inmun yŏn'gu 인문연구 60:327-344.

KWŎN OYǑNG 권오영 [KwON OH YOUNG]

1995 Samhan sahoe 'kuk' ŭi kusŏng e taehan koch'al 삼국사회 ‘國’ 의 구성에 대한 고찰 [A study on the formation of Samhan society 'Guk']. Han'guk kodaesa yŏn'gu 한국고대사연구 10:11-53.

2008 The influence of recent archaeological discoveries on the research of Paekche history, in Early Korea: Reconsidering Early Korean History Through Archaeology: 65-112, ed. M. Byington. Seoul: Early Korea Project, Korea Institute, Harvard University.

2009 Wŏnsamgukki Han'gang yuyŏk chŏngch'i ŭi chonjae yangt'ae wa Paekche kukka ŭi t'onghap yangsang 원삼국기 한강유역 정치체의 존재양태와 백제국가의 통합양상 [The existence of politics on Han-river area in proto three kingdoms period and the integration process of Baekje].Kogohak 고고학 8(2):31-49. 
2010 Mahan ŭi chongjoksŏng kwa kongganjŏk punp'o e taehan kŏmt'o 마한의 종족성과 공간적 분포에 대한 검토 [A study on the ethnicity and spatial distribution of Mahan]. Han'guk kodaesa yŏn'gu 한국고대사연구 60:5-33.

KyŎNGGi Munhwa Chedan 경기문화재단 [GyeOngGi Cultural FOUndation]

2004 Yŏnch'ŏn Hakkong-ni chŏksŏkch'ong 연천 학곡리 적석총 [The Stone Mound Tomb at Hakgok-ri, Yeoncheon]. Suwŏn: Kyŏnggi Munhwa Chedan.

2009 Kap'yŏng Taesŏng-ni yujŏk 가평 대성리 유적 [The Site of Daeseong-ri, Gapyeong]. Suwŏn: Kyŏnggi Munhwa Chedan.

KYŎRE MUNHWA YUSAN YŎN'GUWŎN 겨레문화유산연구원 [GYEORE INSTITUTE OF CUlturAl HeritAGE] 2011 Kap'yŏng Taesŏng-ni yujŏk II 가평 대성리 유적 II [The Site of Daeseong-ri, Gapyeong II]. Koyang: Kyŏre Munhwa Yusan Yŏn'guwŏn.

Lee, Gyoung-AH

2011 The transition from foraging to farming in Prehistoric Korea. Current Anthropology 52 (S4):307-329.

LuCY, SAM

2005 Ethnic and cultural identities, in The Archaeology of Identity: 86-109, ed. M. Diaz-Andreu, S. Lucy, S. Babic, and D. N. Edwards. London: Routledge.

MacEACHERn, SCOTT

1998 Scale, style, and cultural variation: Technological traditions in the northern Mandara Mountains, in The Archaeology of Social Boundaries: 107-131, ed. M. Stark. Washington: Smithsonian Institution Press.

MacSweEney, NaOíse

2009 Beyond ethnicity: The overlooked diversity of group identities. Journal of Mediterranean Archaeology 22(1):101-126.

Martin, ANDREW M.

2013 Archaeology Beyond Postmodernity: A Science of the Social. Lanham, MD: AltaMira Press.

MESKELl, LyNN

2007 Archaeologies of identity, in The Archaeology of Identities: A Reader: 23-43, ed. T. Insoll. London: Routledge.

Nelson, Sarah M.

1993 The Archaeology of Korea. Cambridge, UK: Cambridge University Press.

2010 The politics of ethnicity in Prehistoric Korea, in Contemporary Archaeology in Theory: The New Pragmatism: 290-300, ed. R. Preucel and S. Mrozowski. Maldan, MA: Wiley-Blackwell.

No HYŎKCHIN 노혁진 [Ro HYuk JiN]

2004 Chungdosik t'ogi ŭi yurae e taehan ilgo 중도식토기의 유래에 대한 일고 [The Northeastern Diffusionary Route Model for the origination and spread of the 'Jung-do (中島)' Style Plain Pottery]. Honam kogo hakpo 湖南考古學報 19:97-112.

O’Brian, Michael J., and R. Lee Lyman

2009 Darwinism and historical archaeology, in International Handbook of Historical Archaeology: 227-252, ed. D. Gaimster and T. Majewski. New York: Springer.

PAI, Hyung IL

1992 Culture contact and culture change: The Korean peninsula and its relations with the Han Dynasty commandery of Lelang. World Archaeology 23(3):306-319.

2000 Constructing "Korean" Origins: A Critical Review of Archaeology, Historiography, and Racial Myth in Korean State-Formation Theories. Cambridge, MA: Harvard University Asia Center.

PAK ChungGuK 박중국 [PARK JungKuK]

2011 Wŏnsamgukki Paekche Hansŏng chungbu chiyŏk yŏ chahyŏng chugŏji ŭi pyŏnch'ŏn kwa chiyŏksŏng 원삼국기 백제한성기 중부지역 뭄자형 주거지의 변천과 지역성 [A study on the dwellings of Proto-Three Kingdoms Period and Hanseong Paekche Period through Tunnel-Shaped Heating System]. Kogohak 고고학 101:47-85.

2012 Chungdo munhwa ŭi chiyŏksŏng: ‘chungdo yuhyŏng munhwaron' ŭi chaegŏmt'o rŭl chungsim ŭro 중도문화의 지역성-‘중도유형문화론'의 재검토를 중심으로 [The regionality of Jung-do archeological culture: Reassessment on 'Jung-do cultural assemblage]. Chungang kogo yŏn'gu 중앙고고연구 11:41-88. 
2016 Chungbu chiyŏk tchokkudŭl munhwa ŭi kyet'ong kwa chŏn'gae 중부지역 쪽구들 문화의 계통과 전개 [A study on genealogy and development of Tunnel-Shaped Heating System (TSHS) culture in central region]. Kogohak 고고학 15(1):55-93.

PAK Sunbal 박순발 [PARK SOON-BAL]

1993 Ch'ŏngdonggi-ch'ŏlgi sidae 청동기 - 철기시대 [Bronze Age - Iron Age], in Han'gang yuyŏksa 한강유역사 [History of the Han River Region]: 115-224, ed. Ch'oe Mongnyong 최몽룡. Seoul: Ilchisa.

1996 Hansŏng Paekche kich’ŭng munhwa ŭi sŏnggyŏk: Chungdo yuhyŏng munhwa ŭi sŏnggyŏk ŭl chungsim ŭro 한성백제 기층문화의 성격-중도유형문화의 성격을 중심으로 [The characteristics of Hanseong Baekje's foundational culture: With focus on the attributes of Chungdo type Culture]. Paekche yŏn'gu 백제연구 26:167-181.

2001a Hansŏng Paekche ŭi t'ansaeng 한성 백제의 탄생 [A Study of the State Formation of Paekche]. Seoul: Sŏgyŏng Munhwasa.

$2001 b$ Mahan taeoe kyosŏp ŭi pyŏnch’ŏn kwa Paekche ŭi tŭngjang 마한 대외교섭의 변천과 백제의 등장 [Changes in Mahan's international relations and the appearance of Paekche]. Paekche yŏn'gu 백제연구 33:1-22.

2004 Yoryŏng chŏmt'odae t'ogi munhwa ŭi Hanbando chŏngch'ak kwajŏng 요령 점토대토기문화의 한반도 정착 과정 [The process by which Liaodong Pottery with a Clay Stripe-culture appeared on the Korean peninsula], in Kŭmgang kogo 금강고고 [Keum River Archaeology]: 37-63, ed. Ch'ungch'ŏng Munhwajae Yŏn'guwŏn 충청문화재연구원. Kongju: Ch’ungch’ŏng Munhwajae Yŏn'guwŏn.

Petrie, Cameron A.

2011 "Culture", innovation and interaction across Southern Iran from the Neolithic to the Bronze Age (c. 6500-3000 BC), in Investigating Archaeological Cultures: 151-182, ed. B. W. Roberts and M. Vander Linden. New York: Springer.

Roberts, Benjamin W., and Marc Vander Linden

2011 Investigating archaeological cultures: Material culture, variability, and transmission, in Investigating Archaeological Cultures: 1-21, ed. B. W. Roberts and M. Vander Linden. New York: Springer.

SeOul Taehakkyo Pangmulgwan 서울대학교박물관 [SeOul National University Museum]

2013 Sǒkch'ŏn-dong kobun'gun I 석촌동고분군 I [Seokcheon-dong Mound Tombs I]. Seoul: Seoul Taehakkyo Pangmulgwan.

2015 Sŏkch'ŏn-dong Kobun'gun III 석촌동고분군 III [Seokcheon-dong Mound Tombs III]. Seoul: Seoul Taehakkyo Pangmulgwan.

SHENNAN, STEPHEN

1989 Introduction: Archaeological approaches to cultural identity, in Archaeological Approaches to Cultural Identity: 1-32, ed. S. Shennan. London: Unwin Hyman.

SHODA, SHINYA

2008 A brief introduction to rescue archaeology in South Korea, in Early Korea 2: Reconsidering Early Korean History Through Archaeology: 201-212, ed. M. Byington. Seoul: Early Korea Project, Korea Institute, Harvard University.

SiM CHAEYǑN 심재연 [SHIM JAEYOAUN]

$2007 a$ Kangwŏn-do Chungdosik t'ogi munhwa e poinŭn tongbuk chibang yoso 강원도 중도식토기 문화에 보이는 동북지방 요소 [Elements of the north-eastern region visible in the Jung-do style pottery culture of Gangwon Province], in Kukka hyŏngsŏng e taehan kogohakchǒk chŏpkŭn 국가 형성에 대한 고고학적 접근 [Archaeological Approaches to State Formation]: 485-498. Proceedings of the $31^{\text {st }}$ National Conference of the Korean Archaeological Society, Taechŏn, 2-3 November. Seoul: Han'guk Kogo Hakhoe 한국고고학회.

2007 b Namhan'gang chung-sangnyu chiyŏk ŭi ch'ŏlgi sidae munhwa ŭi t'ŭkching: ch'oegŭn palgul charyo rŭl chungsim uro 남한강 중상류지역의 철기시대 문화의 특징-최근 발굴자료를 중심으로 [Characteristics of Iron-age Culture in upper-middle stream of Namhan River: Focusing on recent excavation materials]. Kogohak 고고학 6(2):39-67.

2008 Kangwŏn Yŏngdong chibang ch’ŏlgi sidae sanghan kwa hahan 강원 영동지방 철기시대 상한과 하한 [Upper Bound and Lower Bound of the Iron Age in Yeongdong Region, Gangwon]. Tongbuga munhwa yŏn'gu 동북아 문화연구 16:37-55. 
2009 Hansŏng Paekchegi ŭi Yŏngdong-Yŏngsŏ 한성백제기의 영 동•영서 [Hanseong Paekche in the Yeongdong-Youngseo Region]. Kogohak 고고학 8(2):51-68.

2010 Hansŏng Paekchegi Han'gang chung-sangnyu chiyŏk ŭi chŏksŏkch'ong e taehan yŏn'gu 한성백제기 한강 중•상류 지역의 적석총에 대한 연구 [The study of Stone-mound-tombs in the up and mid-stream of Han River]. Sŏulhak yŏng'u 서울학연구 39:151-176.

2011 Kyŏngjil mumun t'ogi ŭi kiwŏn 경질무문토기의 기원 [The origin of Hard Plain Pottery]. Kogohak 고고학 10(1):27-45.

SONG MANYŎNG 송만영 [SONG MANYOUNG]

2003 Chungbu chibang Wŏnsamguk munhwa ŭi chŏn'gae kwajŏng kwa Han-Ye chŏngch'ich'e ŭi tonghyang 중부치방 원삼국 문화의 전개 과정과 한예 정치체의 동향 [The developmental process of Proto-Three Kingdoms culture in the Central Region and trends in the HanYe political grouping], in Kangjwa Han'guk kodaesa 강좌 한국고대사 [Lessons in Korean Ancient History]: 101-143, ed. Han'guk kodae sahoe yŏn'guso 韓國古代社會研究所. Seoul: Karakkuk Sajŏk Kaebal Yŏn'guwŏn.

2010 Chungbu chibang Wŏnsamguk sidae chugóji wa ch'wirak 중부지방 원삼국시대 주거지와 취락 [Proto-Three Kingdoms period houses and settlements in the Central Region], in Mahan-Paekche saramdŭl ŭi chugŏ wa sam 마한 •백제 사람들의 주거와 삶 [The Houses and Lives of Mahan and Paekche People]: 202-221, ed. Kungnip Kongju PangmulgwanChungang Munhwajae Yŏn'guwŏn 국랍공주박물관 중앙문화재연구원. Kongju: Ep'ik.

Stark, Miriam T., Mark D. Elson, and Jeffery J. Clark

1998 Social boundaries and technical choices in Tonto Basin prehistory, in The Archaeology of Social Boundaries: 208-231, ed. M. Stark. Washington: Smithsonian Institution Press.

Subbotina, A. L.

2007 Yŏnhaeju, Tuman'gang yuyŏk, Yŏngdong-Yŏngsŏ chiyŏk ŭi saenggye kyŏngje e taehan ch'ai yŏn'gu 연해주, 두만강유역, 영동•영서 지역의 생계경제에 대한 차이 연구 [Research into the differences amongst the subsistence economies of Maritime Siberia, the Tumen River basin, and the Yeongdong-Yeongseo areas], in Kukka hyŏngsŏng e taehan kogohakchŏk chŏpkŭn 국가 형성에 대한 고고학적 접근 [Archaeological Approaches to State Formation]: 499-509. Proceedings of the $31^{\text {st }}$ National Conference of the Korean Archaeological Society, Taechŏn, 2-3 November. Seoul: Han'guk Kogo Hakhoe.

2009 Yŏnhaeju, Tuman'gang yuyŏk, Yŏngdong, Yŏngsŏ chiyŏk ŭi saenggye kyŏngje e taehan ch'ai yŏn'gu 연해주, 두만강 유역, 영동, 영서지역의 생계경제에 대한 차이연구 [A study of the differences between the subsistence economies of Maritime Siberia, the Tumen River basin, and the Yeongdong and Yeongseo areas], in Ch'ŏlgi sidae Han'guk kwa Yŏnhaeju 철기시대 한국과 연해주 [Korea and Maritime Siberia in the Iron Age]: 249-267, ed. Hwandonghae Kogohak Yŏn'guhoe 환동해고고학연구회 [Pan-east Sea Archaeological Research Institute]. Seoul: Churyusŏng Ch'ulp'ansa.

Trigger, Bruce

2006 A History of Archaeological Thought. New York: Cambridge University Press.

Upton, Dell

1996 Ethnicity, authenticity, and invented traditions. Historical Archaeology 30(2):1-7.

Yi HǔIJUN 李熙濬 [LEE HeE-JOON]

2000 Samhan soguk hyŏngsŏng kwajŏng e taehan kogohakchŏk chŏpkŭn ŭi t'ŭl 삼한 소국 형성 과정에 대한 고고학적 접근의 틀 [A discussion on the archeological approaches to the formation of the Three Han states]. Han'guk kogo hakpo 韓國考古學報 43:113-138.

Yi, HYUNHAE

2009 The formation and development of the Samhan, in Early Korea 2: The Samhan Period in Korean History: 17-59, ed. M. Byington. Seoul: Early Korea Project, Korea Institute, Harvard University.

Yi SŎNGJU 李盛周 [LEE SUNG-JoO]

2009 Chungbu chibang Wŏnsamguk sidae chungdosik Mumun t'ogi yŏn'gu 중부지방 원삼국시 대 중도식무문토기 연구 [Study on Chungdo Style Plain Pottery of Proto-Three Kingdoms Period found in the Central Districts]. Sornsa wa kodae 선사와 고대 30:157-186.

Yi SŎNGJU 李盛周 [LEe Sung-Joo], AND KAng SŎNuk 강선욱 [GANG SEON UK]

2009 Ch'odang-dong yujŏk esŏ pon Kangnŭng chiyŏk ŭi Sillahwa kwajŏng 초당동유적에서 본 강릉지역의 신라화 과정 [The process of becoming Silla in the Gangneung area as seen through the Chodang-dong site], in Kangnŭng Ch'odang-dong yujŏk 강릉 초당동 유적 
[Chodang-dong site, Gangneung]: 461-484. Taejŏn: Han'guk Munhwajae Chosa Yŏn'gu Kigwan Hyŏphoe.

Yu ÜNSIK 유은식 [YOO EUN-SHIK]

2006 Tuman'gang yuyŏk ch'ogi ch'ŏlgi munhwa wa chungbu chibang Wŏnsamguk munhwa e taehan il yŏn'gu 두만강유역 초기철기문화와 중부치방 원삼국문화에 대한 일 연구 [A study of the Early Iron Age Culture in the Tumen River Basin and Proto-Three Kingdoms Culture in the Central Region]. Sungsil sahak 숭실사학 19:133-192.

2007 T'ogi ŭi chejak kibŏp ŭro pon Yŏnhaeju wa Kangwŏn-do charyo kŏmt'o 토기의 제작기법으로 본 연해주와 강원도 자료 검토 [An examination of evidence from Maritime Siberia and Kangwŏn province via pottery manufacturing methods], in Kukka hyŏngsŏng e taehan kogohakchŏk chŏpkŭn 국가 형성에 대한 고고학적 접근 [Archaeological Approaches to State Formation]: 511-528. Proceedings of the $31^{\text {st }}$ National Conference of the Korean Archaeological Society, Taechŏn, 2-3 November. Seoul: Han'guk Kogo Hakhoe.

2009 Yŏnhaeju K'ŭrounop'ŭk'a t'ogi wa chungbu chibang chungdosik mumun t'ogi ŭi chejak kibŏp pigyo 연해주 크로우노프카 토기와 중부지방 중도식무문토기의 제작기법 비교 [A comparison of the manufacturing methods for Maritime Siberia's Krounavka Culture Pottery and Chungdo Type Plain Pottery from the Central Region], in Ch'ólgi sidae Han'guk $k w a$ Yŏnhaeju 철기시대 한국과 연해주 [Korea and Maritime Siberia in the Iron Age]: 99-130, ed. Hwandonghae Kogohak Yŏn'guhoe 환동해고고학연구회 [Pan-east Sea Archaeological Research Institute]. Seoul: Churyusŏng Ch'ulp'ansa.

2014 Hanbando pukpu chibang t'ogi munhwa rŭl t'onghae pon chungbu chibang Wŏnsamguk munhwa ŭi kyet'ong 한반도 북부지방 토기문화를 통해 본 중부지방 원삼국문화의 계통 [Genealogy of Proto Three Kingdoms culture in the central region seen through the pottery culture in the northern region of Korean Peninsula]. Kogohak 고고학 133:5-43.

2015 Tongbuk Asia ch'ogi tchokkudŭl ŭi palsaeng kwa chŏn'gae 동북아시아 초기 쪽구들의 발생과 전개 [A study on the occurrence and development of Early Ondol in Northeast Asia]. Kogohak 고고학 14(3):145-178.

Zedeño, María Nieves

2008 Bundled worlds: The roles and interactions of complex objects from the North American plains. Journal of Archaeological Method and Theory 15(4):362-378.

2013 Methodological and analytical challenges in relational archaeologies: A view from the hunting ground, in Relational Archaeologies: Humans, Animals, Things: 117-134, ed. C. Watts. London: Routledge. 